\title{
Holocene sub-centennial evolution of Atlantic water inflow and sea ice distribution in the western Barents Sea
}

\author{
S. M. P. Berben ${ }^{1}$, K. Husum ${ }^{1}$, P. Cabedo-Sanz ${ }^{2}$, and S. T. Belt ${ }^{2}$ \\ ${ }^{1}$ Department of Geology, University of Troms $\varnothing, 9037$ Troms $\varnothing$, Norway \\ ${ }^{2}$ Biogeochemistry Research Centre, School of Geography, Earth and Environmental Sciences, \\ University of Plymouth, Drake Circus, Plymouth PL4 8AA, UK
}

Correspondence to: S. M. P. Berben (sarah.m.berben@uit.no)

Received: 8 July 2013 - Published in Clim. Past Discuss.: 22 August 2013

Revised: 27 November 2013 - Accepted: 2 December 2013 - Published: 23 January 2014

\begin{abstract}
A marine sediment core (JM09-KA11-GC) from the Kveithola Trough at the western Barents Sea margin has been investigated in order to reconstruct sub-surface temperatures and sea ice distribution at a sub-centennial resolution throughout the Holocene. The relationship between past variability of Atlantic water inflow and sea ice distribution has been established by measurement of planktic foraminifera, stable isotopes and biomarkers from sea ice diatoms and phytoplankton.

Throughout the early Holocene (11 900-7300 cal yr BP), the foraminiferal fauna is dominated by the polar species Neogloboquadrina pachyderma (sinistral) and the biomarkers show an influence of seasonal sea ice. Between 10900 and 10700 cal yr BP, a clear cooling is shown both by fauna and stable isotope data corresponding to the so-called Preboreal Oscillation. After 7300 cal yr BP, the sub-polar Turborotalita quinqueloba becomes the most frequent species, reflecting a stable Atlantic water inflow. Sub-surface temperatures reach $6{ }^{\circ} \mathrm{C}$ and biomarker data indicate mainly icefree conditions. During the last $1100 \mathrm{cal} \mathrm{yr} \mathrm{BP}$, biomarker abundances and distributions show the reappearance of lowfrequency seasonal sea ice and the planktic fauna show a reduced salinity in the sub-surface water. No apparent temperature decrease is observed during this interval, but the rapidly fluctuating fauna and biomarker distributions indicate more unstable conditions.
\end{abstract}

\section{Introduction}

Sea ice is a pivotal element of the climate system (e.g. Kvingedal, 2005; Stroeve et al., 2012) and plays a major role in determining ocean circulation in the North Atlantic. There has been a dramatic reduction in Arctic sea ice cover in recent decades (e.g. Comiso et al., 2008) and, in summer 2012, this loss reached its maximum extent within the ca. $30 \mathrm{yr}$ record of satellite sea ice observations (Schiermeier, 2012). Increased sea ice loss in the Arctic Ocean will result in an enhanced Arctic warming, and this will also have a severe impact on climatic conditions in the Northern Hemisphere in general (e.g. extreme winters in Europe) (Francis et al., 2009).

The underlying water masses are of great importance in determining sea ice extent, especially in the high-latitude North Atlantic and adjacent Barents Sea, where sea ice interacts with the inflow of warm saline Atlantic water (Hopkins, 1991). Indeed, some recent studies have suggested that enhanced advection of Atlantic water into the Arctic might be one of the main causes of the recent sea ice decline (Kinnard et al., 2011; Spielhagen et al., 2011), so ice conditions in the Barents Sea are especially influenced by changing oceanic fronts. The interaction between sea ice and Atlantic water also affects salinity regulation and hence the Atlantic Meridional Overturning Circulation (AMOC) (e.g. Rudels et al., 1996; Dieckmann and Hellmer, 2008). As such, the highlatitude North Atlantic, including the western Barents Sea, represents a key study area as it is the main gateway for Atlantic water into the Arctic Ocean (Broecker, 1991). 
Previous studies indicate that Atlantic water inflow in the high-latitude North Atlantic and adjacent Barents Sea has changed throughout the Holocene (Bauch and Weinelt, 1997; Bond et al., 1997; Jennings et al., 2002; Jiang et al., 2002; Sarnthein et al., 2003; Duplessy et al., 2005; Hald et al., 2007; Risebrobakken et al., 2010), and an overall decrease in atmospheric and oceanic temperatures is generally linked to decreasing solar insolation (Berger, 1978; Koç et al., 1993; Kaufman et al., 2004). During the early Holocene, when solar insolation reached a maximum at these latitudes (Laskar et al., 2004), a strong advection of Atlantic water has been observed (e.g. Husum and Hald, 2004; Slubowska et al., 2005; Slubowska-Woldengen et al., 2007); however, several reconstructions of palaeo-temperatures based on alkenones (e.g. Calvo et al., 2002), diatoms (e.g. Andersen et al., 2004; Birks and Koç, 2002; Koç and Jansen, 1994) and planktic foraminifera (e.g. Andersson et al., 2003; Risebrobakken et al., 2003; Sarnthein et al., 2003) show a different timing of this Holocene maximum. Such differences might be explained in terms of regional variations or influences attributed to the different depth habitats or seasonal responses of the various proxies (Moros et al., 2004). For example, Andersson et al. (2010) suggested that discrepancies in SST records could be explained by differences in hydrographic settings (i.e. sea surface versus sub-surface), while Risebrobakken et al. (2011) showed that a strong insolation at high northern latitudes affects temperatures within the summer mixed layer, but not within the waters underneath, thereby amplifying the different roles of oceanic heat advection and orbital forcing.

Superimposed on this overall trend, observations of several millennial-scale changes in surface ocean circulation also exist (e.g. Bauch and Weinelt, 1997; Bond et al., 1997; Duplessy et al., 2001; Jennings et al., 2002; Jiang et al., 2002; Hald et al., 2007). These changes have been attributed to several influences, including the North Atlantic Oscillation (NAO), the Arctic Oscillation and sea ice (Giraudeau et al., 2004; Solignac et al., 2006; Rousse et al., 2006; SlubowskaWoldengen et al., 2007; Goosse and Holland, 2005; Semenov et al., 2009). Further, Orvik and Skagseth (2003) suggested that wind stress curls affect the variability of Atlantic water inflow. Thus, atmospheric changes are important as they influence the strength of the surface water masses, the AMOC and hence Earth's global heat distribution. The precise nature and driving forces behind the variability of Atlantic water inflow and sea ice extent are, however, not well constrained and large uncertainties prevent an accurate prediction of the future state of these polar regions. In order to determine the degree of natural variability, more well-dated and highresolution records are required (e.g. Voronina et al., 2001), especially those that include records of sea ice distribution (Polyak et al., 2010).

In this paper, we describe a new high-resolution record of surface water properties and sea ice distribution in the western Barents Sea in order to provide a better understanding of their variability throughout the Holocene. The core site (Fig. 1) is situated close to the modern day position of the Arctic front (Hopkins, 1991) and is situated in a glacial trough, which acts as a natural sediment trap containing relatively thick Holocene sediments (Rüther et al., 2012). It therefore represents an excellent location for carrying out such a study using planktic foraminiferal fauna, stable isotopes $\left(\delta^{18} \mathrm{O}, \delta^{13} \mathrm{C}\right)$ and sea ice and phytoplankton biomarkers.

\section{Regional oceanography}

An overview of the main surface currents in the highlatitude North Atlantic and adjacent Barents Sea is shown in Fig. 1a. The North Atlantic Current (NAC) is drawn from the south, pushing relatively warm salty Atlantic water $\left(T>2{ }^{\circ} \mathrm{C}, S>35 \%\right.$; Hopkins, 1991$)$ into the northern North Atlantic (Swift, 1986) (Fig. 1a). Subsequently, this Atlantic water spreads into adjoining regions by different branches of the NAC, i.e. the West Spitsbergen Current (WSC) into the Arctic Ocean and the North Cape Current $(\mathrm{NCaC})$ into the Barents Sea (Fig. 1a). The latter current flows partly northwards into the Barents Sea, whereas another branch turns eastwards, parallel with the coastal current system (Loeng, 1991).

Cold, less saline and ice-loaded polar water $\left(T 0-2{ }^{\circ} \mathrm{C}, S\right.$ 33-34.4\%; Hopkins, 1991) coming from the Arctic Ocean is brought into the Atlantic Ocean by the East Greenland Current (EGC) (Rudels et al., 2005) and into the Barents Sea by the East Spitsbergen Current (ESC) and Bear Island Current (BIC). The ESC continues northwards along the inner shelf of western Svalbard (Fig. 1a). When polar and Atlantic water meet in the Barents Sea, they mix and form Arctic water ( $T \sim 0.5^{\circ} \mathrm{C}, S \sim 34.8 \%$; Hopkins, 1991 ), which is characterized by a reduced temperature and salinity, as well as by a seasonal sea ice distribution (Hopkins, 1991). The boundaries between polar/Arctic and Arctic/Atlantic waters correspond to the polar front and Arctic front, respectively. Both fronts represent a sharp climatic gradient in terms of temperature, salinity and sea ice coverage and are amongst the main oceanographic features of the Barents Sea (Hopkins, 1991). Further north, dense deep water is generated due to brine rejection during winter freezing (Midttun, 1985).

Warm and fresh coastal water $\left(T 2-13{ }^{\circ} \mathrm{C}, S 32-35 \%\right.$; Hopkins, 1991) is found on the shelves and off the coast of Norway, with its reduced salinity resulting from freshwater runoff from the Norwegian mainland and Baltic Sea (Blindheim, 1987). This water mass is transported northwards by the Norwegian Coastal Current (NCC) into the south-western Barents Sea, where it continues along the Norwegian and Russian coastline (Aure and Strand, 2001). The coastal front represents the boundary between coastal and Atlantic water. It typically overlies Atlantic water as a westward thinning wedge although, more northwards, the two water masses mix (Sætre, 2007). 

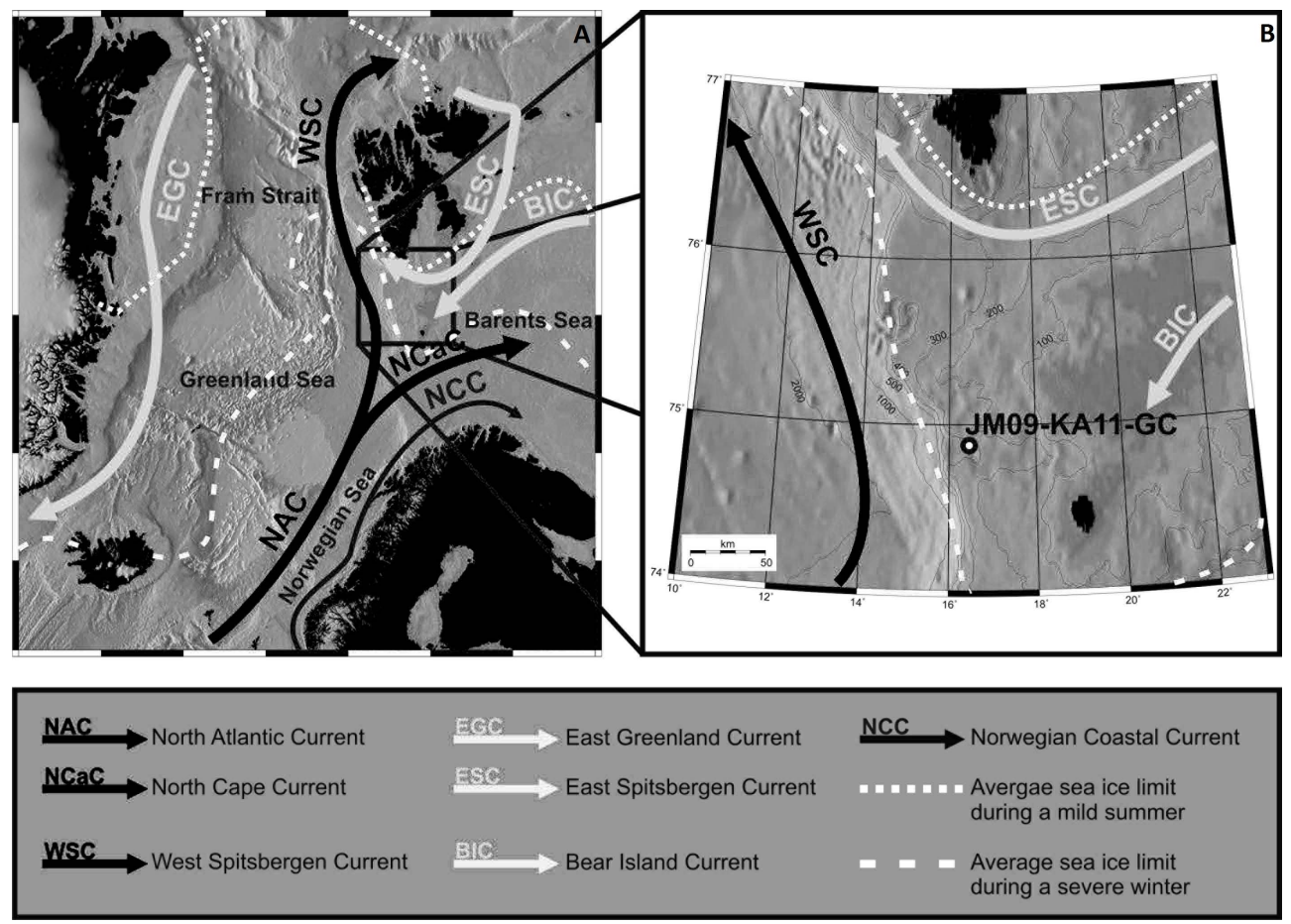

Fig. 1. (A) Surface currents in the high-latitude North Atlantic and north-western Barents Sea are presented on a bathymetric map. Water masses and sea ice distribution are defined according to Hopkins (1991). (B) Close up of the study site showing the core location of JM09KA11-GC. The core was retrieved in the Kveithola Trough surrounded by the Spitsbergen Bank at a water depth of $345 \mathrm{~m}$.

The overall extent of sea ice distribution in the northern North Atlantic and the Barents Sea is closely related to the positions of the polar and Arctic fronts, which align with the average summer and winter sea ice margins, respectively (Vinje, 1977) (Fig. 1a). These fronts determine the position of the marginal ice zone and surface productivity in the summer season (e.g. Smith and Sakshaug, 1990). In the northeastern Barents Sea, Arctic water dominates and sea ice is formed during autumn and winter (Loeng, 1991). In contrast, the southern Barents Sea is characterized by large seasonal and inter-annual sea ice distribution changes due to the strong influence of Atlantic water (Kvingedal, 2005). Nearly all the biological primary production in the Barents Sea results from a peak algal bloom during the spring as ice retreats along the ice edge (Sakshaug et al., 1992). In the western Barents Sea, Atlantic water dominates the water masses and is overlain by fresher and colder surface waters (Loeng, 1991) (Fig. 2).

\section{Material and methods}

Sediment core JM09-KA11-GC was retrieved in 2009 by RV Jan Mayen in the western Barents Sea $\left(74.87^{\circ} \mathrm{N}, 16.48^{\circ} \mathrm{E}\right)$ at a water depth of $345 \mathrm{~m}$ (Rüther et al., 2012) (Fig. 1b). In this study, only the Holocene interval (past $11900 \mathrm{cal} \mathrm{yr} \mathrm{BP)} \mathrm{of}$ the core was analysed. The Holocene interval is represented by the upper $1.3 \mathrm{~m}$ of the core and consists of sediments rich in sand and silt (Rüther et al., 2012).

\subsection{Chronology}

A depth-age model of JM09-KA11-GC was first developed by Rüther et al. (2012). For the current study, five additional AMS ${ }^{14} \mathrm{C}$ dates were obtained and a new depth-age model was developed using linear interpolation (Fig. 3). All 13 AMS ${ }^{14} \mathrm{C}$ dates were calibrated using Calib 7.0.0 software (Stuiver and Reimer, 1993), the Marine13 calibration curve (Reimer et al., 2013) and a local reservoir age $(\Delta \mathrm{R}$ value) of $67 \pm 34$ based on existing data from near Bear Island $\left(74.12^{\circ} \mathrm{N}, 19.07^{\circ} \mathrm{E}\right)$ (Mangerud and Gulliksen, 1975). This calibration was constrained on a $2-\sigma$ range (Table 1 ). Five AMS ${ }^{14} \mathrm{C}$ dates were not included in the final depthage model (Table 1). The AMS ${ }^{14} \mathrm{C}$ date at $4.5 \mathrm{~cm}$ was left out as its 2- $\sigma$ range was larger than the subsequent AMS ${ }^{14} \mathrm{C}$ date at $4.5 \mathrm{~cm}$. Three other AMS ${ }^{14} \mathrm{C}$ dates, one at $33.0 \mathrm{~cm}$ and two at $82.5 \mathrm{~cm}$, appeared to be too young, most likely due to the downward migration of the infaunal molluscs $A s$ tarte elliptica and Nuculana minuta. An additional AMS ${ }^{14} \mathrm{C}$ date at $111.0 \mathrm{~cm}$ on benthic foraminifera appeared too old when listing all AMS ${ }^{14} \mathrm{C}$ dates, including those from the lower most part of the core covering the Younger Dryas and deglaciation (Rüther et al., 2012). Although carbon dating of molluscs may be problematic (e.g. Mangerud et al., 2006), it 


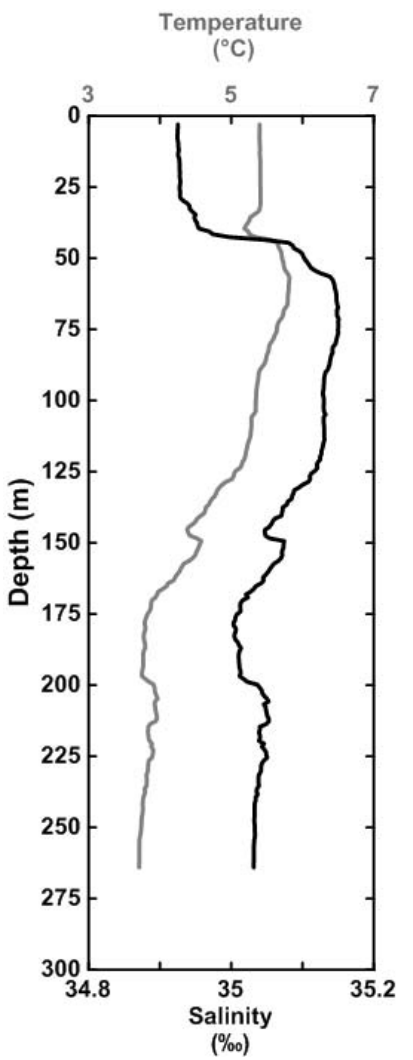

Fig. 2. Temperature (grey) and salinity (black) profile from the JM09-KA11-GC core location measured on 13 July 2009 (GlaciBar).

appears that this date is reworked when comparing it to the succession of all AMS ${ }^{14} \mathrm{C}$ dates. Hence, it was left out of the depth-age model. Other radiocarbon dates on molluscs appeared not to be reworked when evaluating all AMS ${ }^{14} \mathrm{C}$ dates together and thus they were included in the depth-age model. The resulting depth-age model showed sedimentation rates between 0.03 and $0.25 \mathrm{~mm} \mathrm{yr}^{-1}$ corresponding to a sub-centennial (20-159 yr $/ 0.5 \mathrm{~cm}$ ) resolution (Fig. 3).

\subsection{Background to proxies}

Sea surface and sub-surface temperatures are often reconstructed using faunal assemblages and stable isotopic analysis of planktic foraminifera (e.g. Eynaud, 2011) and quantitative reconstructions can be obtained through the application of transfer functions (e.g. Imbrie and Kipp, 1971; Pflaumann et al., 2003; Kucera et al., 2005). Recently, Husum and Hald (2012) developed an Arctic training set based on the $>100 \mu \mathrm{m}$ size fraction and found that the most robust reconstructions of sea surface temperatures using transfer functions were obtained when using summer temperatures from sub-surface water masses at $100 \mathrm{~m}$ water depth.

In recent years, seasonal Arctic sea ice conditions have been derived by analysis of the sea ice diatom biomarker $\mathrm{IP}_{25}$

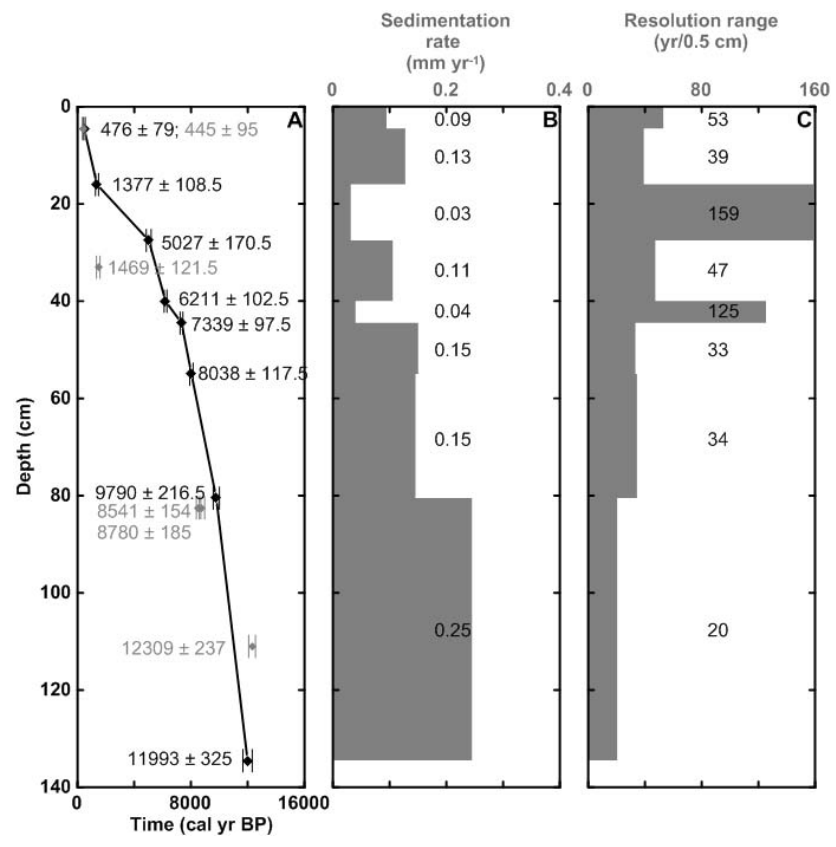

Fig. 3. (A) Depth-age model of the upper $134.5 \mathrm{~cm}$ of JM09-KA11$\mathrm{GC}$ based on eight calibrated AMS ${ }^{14} \mathrm{C}$ dates and a linear interpolation between the calibrated radiocarbon ages. The $2-\sigma$ range of each calibrated radiocarbon age is indicated by an error bar, whereas the exact value is noted (omitted ages in grey). (B) Sedimentation rates versus core depth. (C) Resolution range versus core depth.

(Belt et al., 2007; Belt and Müller, 2013). $\mathrm{IP}_{25}$ is a $\mathrm{C}_{25}$ monounsaturated highly branched isoprenoid (HBI) lipid produced specifically by Arctic sea ice diatoms and appears to be relatively stable in marine sediments (Brown et al., 2011; Belt and Müller, 2013; Stein and Fahl, 2013). Importantly, in a number of studies, variable abundances of sedimentary $\mathrm{IP}_{25}$ have been shown to be consistent with known sea ice trends or have provided new information regarding palaeosea-ice-cover conditions (Belt and Müller, 2013, and references therein). Since the absence of $\mathrm{IP}_{25}$ from Arctic marine sediments is believed to either represent open water or perennial ice cover, the additional determination of brassicasterol and other phytoplankton lipids has been used to distinguish between these two oceanographic extremes (e.g. Müller et al., 2009, 2011; Belt and Müller, 2013). With respect to the current study location, Vare et al. (2010) observed a good correlation between $\mathrm{IP}_{25}$ data and historical records of sea ice covering the last few centuries for the Barents Sea and suggested that longer term palaeo-sea-ice records beyond the historical data should therefore be achievable using the same approach. In addition, Navarro-Rodriguez et al. (2013) showed that the occurrence of $\mathrm{IP}_{25}$ in surface sediments from the Barents Sea was extremely sensitive to sea ice cover in recent decades. 
Table 1. AMS ${ }^{14} \mathrm{C}$ dates and calibrated radiocarbon ages of JM09-KA11-GC. The calibration is based on the Marine13 calibration curve (Reimer et al., 2013) and a regional $\Delta \mathrm{R}$ of $67 \pm 34$. The dates which are not used in the final depth-age model are indicated in italics.

\begin{tabular}{|c|c|c|c|c|c|c|c|}
\hline Lab ID & Core depth & Material & $\begin{array}{c}{ }^{14} \mathrm{C} \text { yr } \\
\mathrm{BP} \text { (uncorrected) }\end{array}$ & $1 \sigma$ & cal yr BP & $2-\sigma$ range & Reference \\
\hline Tra-1063 & $4.5 \mathrm{~cm}$ & Mollusc dextral part of Bathyarca glacialis & 925 & 30 & 476 & $397-555$ & Rüther et al. (2012) \\
\hline Tra-1064 & $4.5 \mathrm{~cm}$ & Mollusc dextral part of Bathyarca glacialis & 900 & 35 & 445 & $354-535$ & Rüther et al. (2012) \\
\hline Tra-1065 & $16.0 \mathrm{~cm}$ & Mollusc sinistral part of Bathyarca glacialis & 1880 & 35 & 1377 & $1268-1485$ & Rüther et al. (2012) \\
\hline Beta-324049 & $27.5 \mathrm{~cm}$ & Benthic foraminifera Islandiella norcrossi/helenae & 4820 & 30 & 5027 & $4856-5197$ & This study \\
\hline Tra-1066 & $33.0 \mathrm{~cm}$ & Mollusc dextral part of Astarte elliptica & 1990 & 35 & 1469 & $1347-1590$ & Rüther et al. (2012) \\
\hline Beta-315192 & $40.0 \mathrm{~cm}$ & Benthic foraminifera Islandiella norcrossi/helenae & 5870 & 30 & 6211 & $6108-6313$ & This study \\
\hline Beta-315193 & $44.5 \mathrm{~cm}$ & Benthic foraminifera Islandiella norcrossi/helenae & 6890 & 40 & 7339 & $7241-7436$ & This study \\
\hline Tra-1067 & $55.0 \mathrm{~cm}$ & Mollusc sinistral part of Astarte sulcata & 7630 & 45 & 8038 & $7919-8154$ & Rüther et al. (2012) \\
\hline Beta-315194 & $80.5 \mathrm{~cm}$ & Benthic foraminifera Islandiella norcrossi/helenae & 9140 & 40 & 9790 & $9573-10006$ & This study \\
\hline Tra-1068 & $82.5 \mathrm{~cm}$ & Mollusc paired shell of Astarte elliptica & 8140 & 50 & 8541 & $8387-8695$ & Rüther et al. (2012) \\
\hline Tra-1069 & $82.5 \mathrm{~cm}$ & Mollusc sinistral part of Nuculana minuta & 8315 & 50 & 8780 & $8595-8965$ & Rüther et al. (2012) \\
\hline Beta-315195 & $111.0 \mathrm{~cm}$ & Benthic foraminifera Elphidium excavatum & 10900 & 50 & 12309 & $12072-12546$ & This study \\
\hline Tra-1070 & $134.5 \mathrm{~cm}$ & Mollusc paired shell of Yoldiella intermedia & 10705 & 55 & 11993 & $11668-12318$ & Rüther et al. (2012) \\
\hline
\end{tabular}

Table 2. Planktic foraminiferal species list.

\begin{tabular}{l}
\hline Planktic foraminiferal species \\
\hline Globigerina bulloides (d'Orbigny, 1826) \\
Globigerinita glutinata (Egger, 1893) \\
Globigerinita uvula (Ehrenberg, 1861) \\
Neogloboquadrina incompta (Cifelli, 1961) \\
Neogloboquadrina pachyderma (sinistral) (Ehrenberg, 1861) \\
Turborotalita quinqueloba (Natland, 1838)
\end{tabular}

\subsection{Planktic foraminifera}

The JM09-KA11-GC core was sampled for planktic foraminifera every $0.5 \mathrm{~cm}$. The samples were freeze-dried, wet-sieved into different size fractions using 1000, 100 and $63 \mu \mathrm{m}$ mesh size sieves and dried in an oven at $40^{\circ} \mathrm{C}$. Due to a low abundance of planktic foraminifera in the samples between 90.0 and $130.0 \mathrm{~cm}$, the foraminifera in these samples were separated from the sediment using sodium polytungstate diluted with distilled water to a specific gravity of $1.8 \mathrm{~g} \mathrm{~mL}^{-1}$ following Knudsen (1998). One hundred and twenty-seven samples were analysed with regard to the planktic foraminifera using the $100-1000 \mu \mathrm{m}$ size fraction according to Knudsen (1998). The identification of left- and right-coiling Neogloboquadrina pachyderma was done following Darling et al. (2006) (Table 2). A minimum of 300 specimens was identified for each sample, although when calculating relative and absolute abundances, 57 samples containing planktic foraminifera between 50 and 300 specimens were still included. Relative abundances (\%) and fluxes (no. specimens $\mathrm{cm}^{-2} \mathrm{yr}^{-1}$ ) were calculated for each sample. Fluxes were calculated according to Ehrmann and Thiede (1985) using dry bulk densities, which were calculated using the water content and wet bulk density measurements of Rüther et al. (2012).
Planktic foraminifera can be exposed to carbonate dissolution associated with ocean circulation and climate (e.g. Archer and Maier-Reimer, 1994; Archer, 1996). As dissolution might have affected the planktic foraminifera assemblages in JM09-KA11-GC, it was considered important to quantify the state of foraminiferal preservation. Hence, the mean shell weight of $N$. pachyderma (sin.) was measured (Broecker and Clark, 2001; Barker and Elderfield, 2002; Beer et al., 2010). Visually well-preserved and square-shaped forms of $N$. pachyderma (sin.) were weighed using a Mettler Toledo microbalance $(0.1 \mu \mathrm{g}$ sensitivity). To minimize problems of ontogeny and variability due to size differences, the tests were picked within a narrow size fraction of 230 $290 \mu \mathrm{m}$ (Barker et al., 2004). Further, the fragmentation of foraminiferal tests was analysed in the $100-1000 \mu \mathrm{m}$ size fraction, as this also reflects the degree of dissolution (Conan et al., 2002). The fragmentation (\%) was calculated using the method of Pufhl and Shackleton (2004) (Eq. 1).

Fragmentation $(\%)=\frac{\text { no. fragments } g^{-1}}{\text { no. fragments } g / 3+\text { no. test } \mathrm{g}^{-1}} * 100$

In using Eq. (1), it was assumed that each shell breaks into more than one fragment, and therefore the total number of fragments per sample was divided by three. The use of a divisor reduces misinterpretations of the dissolution sensitivity in changes and progress (Le and Shackleton, 1992; Pufhl and Shackleton, 2004).

Finally, summer (July-August-September) sub-surface temperatures (sSST) were reconstructed for a water depth of $100 \mathrm{~m}$ using the improved modern training set of Husum and Hald (2012). The weighted average partial least square (WA-PLS) and maximum likelihood (ML) statistical models with a leave-one-out cross validation were applied (Ter Braak and Juggins, 1993; Telford and Birks, 2005). The calculations were carried out using the computer program C2 version 1.7.2 (Juggins, 2010). 


\subsection{Stable isotope analysis}

Stable isotope analysis $\left(\delta^{13} \mathrm{C}\right.$ and $\left.\delta^{18} \mathrm{O}\right)$ was carried out on 132 samples, giving a sub-centennial resolution. Foraminiferal tests of $N$. pachyderma (sin.) from the 100 $1000 \mu \mathrm{m}$ size fraction were analysed. Measurements were performed with a Finnigan MAT 253 mass spectrometer coupled to an automated Kiel device at the Geological Mass Spectrometer (GMS) Laboratory of the University of Bergen. The data were reported on the VPDB scale (calibrated with NBS-19) and measurements were conducted with a reproducibility of $\pm 0.04 \% o\left(\delta^{13} \mathrm{C}\right)$ and $\pm 0.06 \%$ o $\left(\delta^{18} \mathrm{O}\right)$. The resulting $\delta^{18} \mathrm{O}$ values were corrected for the ice volume effect according to Fairbanks (1989). The isotope measurements in this study were not corrected for their species-specific vital effect as published estimates in the literature are often inconsistent, possibly due to apparent change between seasons (Jonkers et al., 2010).

\subsection{Biomarker analysis}

Individual sub-samples for biomarker analysis were taken at $0.5 \mathrm{~cm}$ intervals, freeze-dried and stored at $-20^{\circ} \mathrm{C}$ prior to analysis. Biomarker analysis ( $\mathrm{IP}_{25}$ and sterols) was performed using methods described previously (Brown et al., 2011; Belt et al., 2012) but with some modifications. Briefly, three internal standards were added to each freeze-dried sediment sample to permit quantification of lipid biomarkers. Specifically, 7-hexylnonadecane (7-HND, $10 \mu \mathrm{L} ; 10 \mu \mathrm{g} \mathrm{mL}^{-1}$ ) and 9-octylheptadec-8-ene (9-OHD, $10 \mu \mathrm{L} ; 10 \mu \mathrm{g} \mathrm{mL}^{-1}$ ) were added for quantification of $\mathrm{IP}_{25}$ and $5 \alpha$-androstan- $3 \beta$-ol $\left(10 \mu \mathrm{L} ; 10 \mu \mathrm{g} \mathrm{mL}^{-1}\right)$ was added for quantification of sterols. Sediments were then extracted using dichloromethane/methanol $(3 \times 3 \mathrm{~mL}, 2: 1 \mathrm{v} / \mathrm{v})$ and ultrasonication before decanting and drying (Brown et al., 2011; Belt et al., 2012). Since many total organic extracts (TOEs) were found to contain high concentrations of elemental sulfur that interfered with the subsequent gas chromatographic analyses, this was removed from the primary extracts before further purification. This was achieved through the addition of hexane $(1 \mathrm{~mL})$, tetrabutylammonium sulfite (TBA, $1 \mathrm{~mL})$ and 2-propanol $(2 \mathrm{~mL})$ to the dried TOEs, which were then shaken by hand (1 min). After addition of ultrahigh-purity water $(3 \mathrm{~mL})$, the samples were shaken again $(1 \mathrm{~min})$ and centrifuged. The hexane layer (containing the lipids of interest) was transferred to a clean vial and the procedure repeated twice more. Following removal of the solvent from the combined hexane extracts using nitrogen, the resulting TOEs were purified using column chromatography (silica), with $\mathrm{IP}_{25}$ and other hydrocarbons (hexane, $6 \mathrm{~mL}$ ) and sterols (20:80 methylacetate/hexane, $6 \mathrm{~mL})$ collected as two single fractions. In some cases, the identification or quantification of $\mathrm{IP}_{25}$ in these partially purified extracts was made difficult due to a combination of low concentrations and the occurrence of other highly abundant co- eluting organic compounds that prevented further concentration of the extracts. Therefore, hexane extracts were further fractionated into saturated and unsaturated components using glass pipettes containing silver ion solid-phase extraction (SPE) material (Supelco discovery ${ }^{\circledR} \mathrm{Ag}$-Ion). Saturated hydrocarbons were eluted first (hexane, 5 column volumes, then dichloromethane, 5 column volumes) and unsaturated hydrocarbons (including $\mathrm{IP}_{25}$ ) were eluted with dichloromethane / acetone (95/5, 5 column volumes) before being dried (nitrogen). Analysis of individual fractions was carried out using gas chromatography-mass spectrometry (GC-MS) and operating conditions were as described previously (e.g. Belt et al., 2012; Brown and Belt, 2012). Sterols were derivatized (N,O-Bis(trimethylsilyl)trifluoroacetamide; $\left.50 \mu \mathrm{L}, 70^{\circ} \mathrm{C}, 1 \mathrm{~h}\right)$ prior to analysis by GC-MS. Massspectrometric analysis was carried out either in total ion current (TIC) or single-ion monitoring (SIM) mode. Individual lipids were identified on the basis of their characteristic GC retention indices and mass spectra obtained from standards. Quantification of lipids was achieved by comparison of mass spectral responses of selected ions (SIM mode) with those of the internal standards and normalized according to relative response factors and sediment masses (Belt et al., 2012). Analytical reproducibility was monitored using a standard sediment with known abundances of biomarkers for every 16 to 18 sediment samples extracted (analytical error $<5 \%$, $n=4)$. All biomarker concentrations ( $\mu \mathrm{g} \mathrm{g}^{-1}$ sediment) were normalized to total organic carbon content $\left(\mu \mathrm{g} \mathrm{g}^{-1} \mathrm{OC}\right)$ and also converted to fluxes $\left(\mu \mathrm{g} \mathrm{cm}^{-2} \mathrm{yr}^{-1}\right)$ as per the method used for foraminifera.

Individual biomarker data were not combined to derive corresponding PIP 25 data (Müller at al., 2011) for two reasons. First, Navarro-Rodriguez et al. (2013) showed that the $\mathrm{PIP}_{25}$-based approach for semi-quantitative sea ice reconstruction does not work well for recent sea ice conditions for the Barents Sea. Second, the data presented here correspond to the Holocene epoch only; however, additional biomarker data from the same core covering the Younger Dryas (not shown) indicate that the so-called balance factor $(c)$ used in the calculation of the $\mathrm{PIP}_{25}$ data is highly variable depending on the section of core under study. This has previously been identified as a potential limitation of this approach (Belt and Müller, 2013) and the current study exemplifies this further.

\section{Results}

\subsection{Planktic foraminifera}

The planktic foraminiferal fauna consists of six species and is dominated by two: Neogloboquadrina pachyderma (sin.) and Turborotalita quinqueloba. Neogloboquadrina incompta, Globigerinita uvula and Globigerinita glutinata are also observed, but as minor species. Further, Globigerina 
bulloides is found sporadically throughout the record (Table 2; Fig. 4a-f).

The early part of the record (11900-9900 cal yr BP) is dominated by $N$. pachyderma (sin.) with a percentage abundance of ca. $60 \%$ and a maximum is observed at $10800 \mathrm{cal} \mathrm{yr} \mathrm{BP} \mathrm{(84 \% )} \mathrm{(Fig.} \mathrm{4a).} \mathrm{Between} 11900$ and 10800 cal yr BP, $N$. incompta shows a decrease, followed by an increase, reaching its maximum relative abundance of $30 \%$ at 10400 calyr BP. This is followed by a decrease between 10400 and $7300 \mathrm{calyrBP}$ towards $6 \%$ (Fig. 4c). T. quinqueloba becomes the most frequent species at $9900 \mathrm{cal}$ yr BP and increases continuously up to 8000 cal yr BP (Fig. 4b). From 7300 to 1100 cal yr BP the relative abundances of all six recorded species remain relatively stable, with $T$. quinqueloba as the most dominant species (ca. $65 \%$ ) (Fig. 4a-f). The last 1100 cal yr BP is characterized by a decrease in T. quinqueloba and $N$. incompta and an increase in G. glutinata and G. bulloides (Fig. 4b-f). The most prominent feature of this period, however, is the rather sharp increase in G. uvula of almost $10 \%$ (Fig. 4d).

Both the total absolute abundances of planktic foraminifera (per gram dry sediment) and the total fluxes of foraminifera show very low values in the early part of the record (11 900-9900 cal yr BP) (Fig. 4g). At ca. $10400 \mathrm{cal}$ yr BP, the total foraminiferal flux increases sharply towards $9900 \mathrm{calyr}$ BP reaching ca. 100 specimens $\mathrm{cm}^{-2} \mathrm{yr}^{-1}$. The increase in concentration starts after ca. $10000 \mathrm{cal} \mathrm{yr} \mathrm{BP}$ and reaches values of ca. 5000 specimens $\mathrm{g}^{-1}$ in ca. $1000 \mathrm{yr}$. Between 9900 and $7300 \mathrm{cal} \mathrm{yr} \mathrm{BP,}$ the concentration continues to fluctuate around 4000 specimens $\mathrm{g}^{-1}$, and the flux decreases to values around 10 to 20 specimens $\mathrm{cm}^{-2} \mathrm{yr}^{-1}$. From ca. 7300 cal yr BP, concentrations continue to gently increase, whereas fluxes remain relatively constant. In the more recent part of the record, the flux reaches a value of $>60$ specimens $\mathrm{cm}^{-2} \mathrm{yr}^{-1}$ at 1100 cal yr BP, whereas the concentration shows a sharp increase, extending to values of 6000 specimens $\mathrm{g}^{-1}$.

The shell weight and fragmentation are inversely correlated throughout the record (Fig. 4h). Between 11900 and 10300 cal yr BP, the mean shell weight decreases from approximately 5 to $3 \mu \mathrm{g}$, whereas the shell fragmentation increases from ca. 10 to $30 \%$. This period is followed by a rapid increase in shell weight from 3 to $10 \mu \mathrm{g}$ and a simultaneous decrease in shell fragmentation from 30 to $5 \%$. Between 9900 and $1100 \mathrm{cal} \mathrm{yr} \mathrm{BP}$, the values are relatively stable, showing a mean shell weight and fragmentation of ca. $7 \mu \mathrm{g}$ and $10 \%$, respectively (Fig. 4h). Finally, from 1100 cal yr BP towards the present day, the shell weight decreases to ca. $5 \mu \mathrm{g}$, whereas the fragmentation remains stable at around $10 \%$.

Different statistical models have been tested in order to reconstruct SSST records and their performance characteristics are evaluated following Birks (1995) (Table 3). A WA-PLS component 3 model is selected as the most appropriate model to obtain a precise estimation. This choice is based on a com-
Table 3. Performance characteristics of transfer function models used to reconstruct palaeo-sSST of JM09-KA11-GC. Italics indicate the statistical model with the best performance values according to Birks (1995).

\begin{tabular}{lcccc}
\hline Transfer function & $\begin{array}{c}\text { Water } \\
\text { depth }(\mathrm{m})\end{array}$ & $\begin{array}{c}\text { Max. } \\
\text { bias }\end{array}$ & RMSEP & \\
\hline WA-PLS Component 1 & 100 & 0.60 & 0.56 & 0.91 \\
WA-PLS Component 2 & 100 & 0.55 & 0.52 & 0.92 \\
WA-PLS Component 3 & 100 & 0.53 & 0.52 & 0.93 \\
WA-PLS Component 4 & 100 & 0.56 & 0.52 & 0.93 \\
WA-PLS Component 5 & 100 & 0.55 & 0.52 & 0.93 \\
ML & 100 & 1.33 & 0.80 & 0.86 \\
\hline
\end{tabular}

bination of the lowest root-mean-square error of prediction $(\mathrm{RMSEP}=0.52)$, the highest correlation between observed and estimated values $\left(R^{2}=0.93\right)$ and the lowest maximum bias (max. bias $=0.53$ ) (Birks, 1995) (Table 3). The foramderived sSST record shows a gradual warming from 4 to $5^{\circ} \mathrm{C}$ between 11900 and $10400 \mathrm{cal}$ yr BP (Fig. 4i). This period is interrupted by an abrupt and short cooling event of ca. $2.5^{\circ} \mathrm{C}$ around $10800 \mathrm{cal} \mathrm{yr} \mathrm{BP}$. From 10400 to $8000 \mathrm{cal} \mathrm{yr} \mathrm{BP}$, the record shows a more gradual increase up to $6{ }^{\circ} \mathrm{C}$, where it remains stable to present (Fig. 4i).

\subsection{Stable isotope analysis}

The $\delta^{18} \mathrm{O}$ and $\delta^{13} \mathrm{C}$ measurements of $N$. pachyderma (sin.) show similar general trends throughout the record (Fig. 5). Overall, the $\delta^{18} \mathrm{O}$ values are in the range 1.79 to $2.90 \%$ o (Fig. 5a). Between 11900 and $11300 \mathrm{cal} \mathrm{yr} \mathrm{BP,} \delta^{18} \mathrm{O}$ values show a slight depletion followed by a small enrichment towards 10800 cal yr BP. Subsequently, a sharp depletion in $\delta^{18} \mathrm{O}$ is observed at ca. $10400 \mathrm{cal}$ yr BP (Fig. 5a), after which $\delta^{18} \mathrm{O}$ values gradually increase up to ca. $2.50 \%$ until ca. $7300 \mathrm{cal}$ yr BP. The $\delta^{18} \mathrm{O}$ record then remains relatively stable until $1100 \mathrm{cal}$ yr BP with a mean value of $2.50 \%$. For the last $1100 \mathrm{cal}$ yr BP, the record shows slightly increased values (Fig. 5a).

The $\delta^{13} \mathrm{C}$ record is within the range -0.30 to $0.86 \%$ (Fig. 5b). A slight depletion in $\delta^{13} \mathrm{C}$ is recorded between 11900 and 11500 cal yr BP, followed by a small enrichment towards 10700 cal yr BP and a sharp depletion with values of $-0.26 \%$ o towards ca. 10400 cal yr BP. Between ca. 10400 and $7300 \mathrm{cal} \mathrm{yr} \mathrm{BP,} \delta^{13} \mathrm{C}$ values increase to $0.40 \%$. For the remaining part of the record, a relatively stable trend is observed with a mean value of ca. $0.40 \%$.

\subsection{Biomarker analysis}

The concentration profiles of $\mathrm{IP}_{25}$ and the two sterols - 24-methylcholesta-5,22E-dien-3 $\beta$-ol (brassicasterol) and 24-methylcholesta-5,24(28)-dien-3 $\beta$-ol (24methylenecholesterol) - are shown in Fig. 6. At 


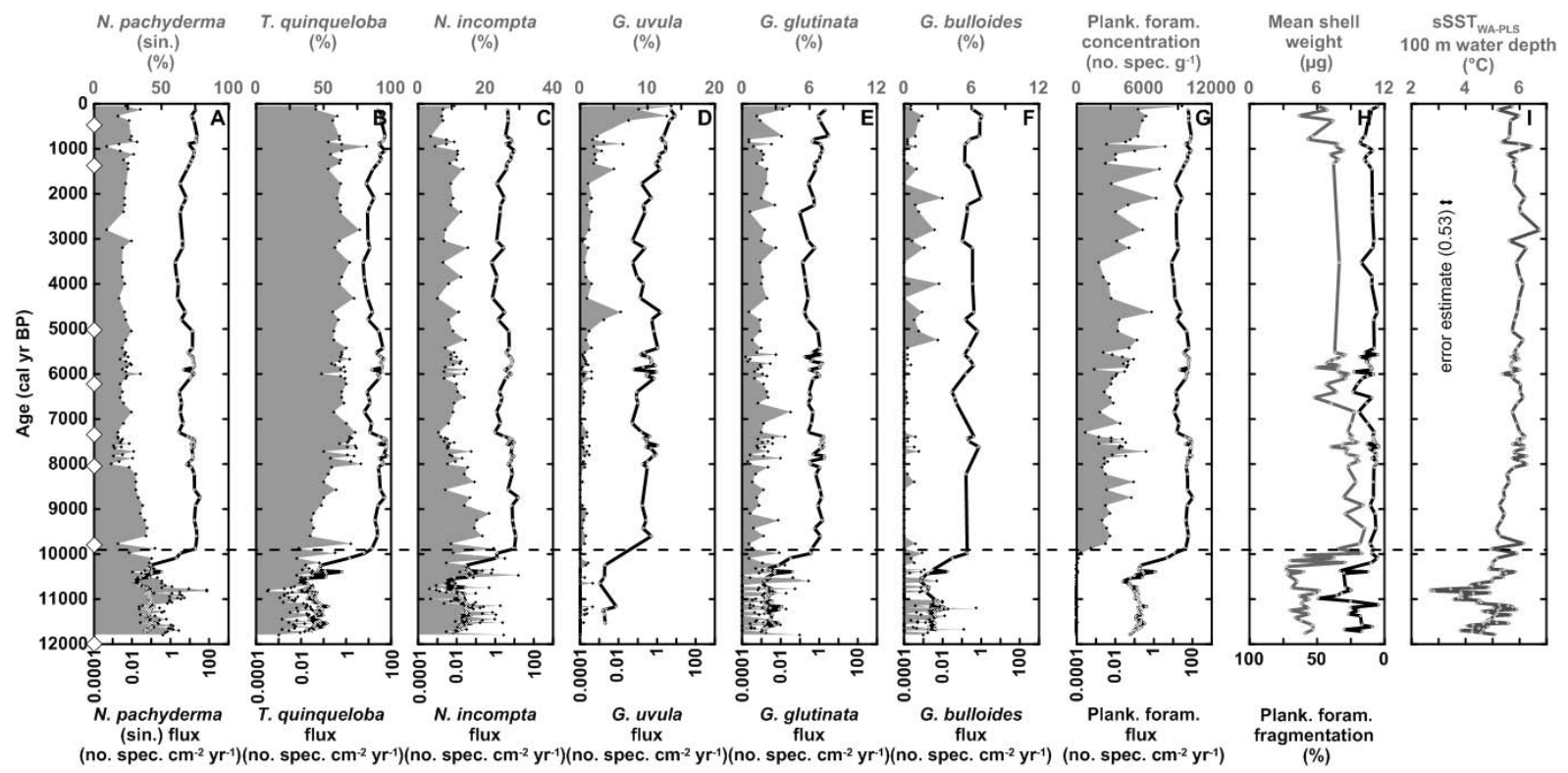

Fig. 4. Planktic foraminiferal analysis plotted versus cal yr BP. The white diamonds on the $y$ axis denote the AMS ${ }^{14} \mathrm{C}$ converted to calibrated radiocarbon ages. Samples below the dotted line contain $<300$ planktic foraminiferal specimens. (A-F) Species-specific relative distribution (grey-filled area) and flux (black line) (note the logarithmic scale for the fluxes). (G) Total planktic foraminiferal concentration (greyfilled area) and flux (black line) (note the logarithmic scale for the fluxes). (H) Mean shell weight (grey line) and planktic foraminiferal fragmentation (black line) (note the reversed axis). (I) Reconstructed sSST WA-PLS.

11900 cal yr BP the $\mathrm{IP}_{25}$ concentration is at its highest value $\left(2.11 \mu \mathrm{g} \mathrm{g}^{-1} \mathrm{OC}\right)$ in the entire record, while the brassicasterol $\left(20.18 \mathrm{\mu g} \mathrm{g}^{-1} \mathrm{OC}\right)$ and 24-methylenecholesterol $\left(5.45 \mu \mathrm{g} \mathrm{g}^{-1}\right.$ OC) concentrations are relatively low at this point. At the onset of the Holocene (ca. $11700 \mathrm{cal} \mathrm{yr} \mathrm{BP}$ ), there is a sharp decrease in $\mathrm{IP}_{25}$ and a simultaneous increase in brassicasterol and 24-methylenecholesterol concentrations. Between ca. 11300 and 9900 cal yr BP, $\mathrm{IP}_{25}$ concentrations remain relatively constant at ca. $0.25 \mu \mathrm{g} \mathrm{g}^{-1} \mathrm{OC}$, while those of brassicasterol and 24-methylenecholesterol increase after ca. $11300 \mathrm{calyr} \mathrm{BP}$, reaching their highest values (51.09 and $18.97 \mu \mathrm{gg}^{-1} \mathrm{OC}$, respectively) at ca. $10400 \mathrm{cal}$ yr BP followed by a decrease towards ca. 9900 cal yr BP. Between 9900 and 1100 cal yr BP, both $\mathrm{IP}_{25}$ and 24-methylenecholesterol are either absent or very low in concentration, but brassicasterol is still present, albeit in very low concentrations of ca. $9.00 \mu \mathrm{g} \mathrm{g}^{-1}$ OC. During the final part of the record (1100-0 cal yr BP), there is a clear increase in brassicasterol concentrations, reaching $60.95 \mu \mathrm{g} \mathrm{g}^{-1}$ OC at the top of the core. In contrast, $\mathrm{IP}_{25}$ continues to be present, but at a very low concentration (ca. $0.10 \mu \mathrm{g} \mathrm{g}^{-1} \mathrm{OC}$ ). The concentrations of all three biomarkers are substantially lower in the recent interval $(<\mathrm{ca} .1100 \mathrm{cal}$ yr BP) compared to those found in the early part of the record, with the exception of brassicasterol, which has reasonably elevated concentrations during the last ca. $500 \mathrm{cal}$ yr BP. Finally, biomarker concentration profiles align closely with fluxes throughout the record (Fig. 6).

\section{Discussion}

The different proxy data in this study indicate palaeoceanographic changes of sub-surface temperatures and sea ice conditions in the western Barents Sea during the Holocene. These changes are discussed according to five time periods identified through analysis of all proxy data (Fig. 7). Period I represents the period 11900 to 10400 cal yr BP (early Holocene) with a short interval defined as sub-period Ia between 10900 and $10700 \mathrm{cal} \mathrm{yr} \mathrm{BP} \mathrm{(Preboreal} \mathrm{Oscillation).}$ Period II constitutes the period from 10400 to 7300 cal yr BP (early-mid-Holocene), period III represents the interval from 7300 to 1100 cal yr BP (mid-late Holocene) and period IV covers the last 1100 cal yr BP (late Holocene-present).

\subsection{Period I: 11 900-10 400 cal yr BP (early Holocene)}

The planktic foraminiferal fauna distribution is characterized by a clear dominance of $N$. pachyderma (sin.), which is associated with cold Arctic and polar water (Volkmann, 2000) (Fig. 7a). The high relative abundance of $N$. pachyderma (sin.) $(60 \%)$ agrees well with data from previous studies. For example, Ebbesen et al. (2007) found a high abundance of this species (up to $80 \%$ ) when investigating the $>100 \mu \mathrm{m}$ size fraction in a sediment core from the western Svalbard margin. Further, Sarnthein et al. (2003) found a similar abundance of $N$. pachyderma (sin.) (ca. 50\%) during this time interval in a core slightly west of the current study site, although they analysed a different size fraction $(>150 \mu \mathrm{m})$. 

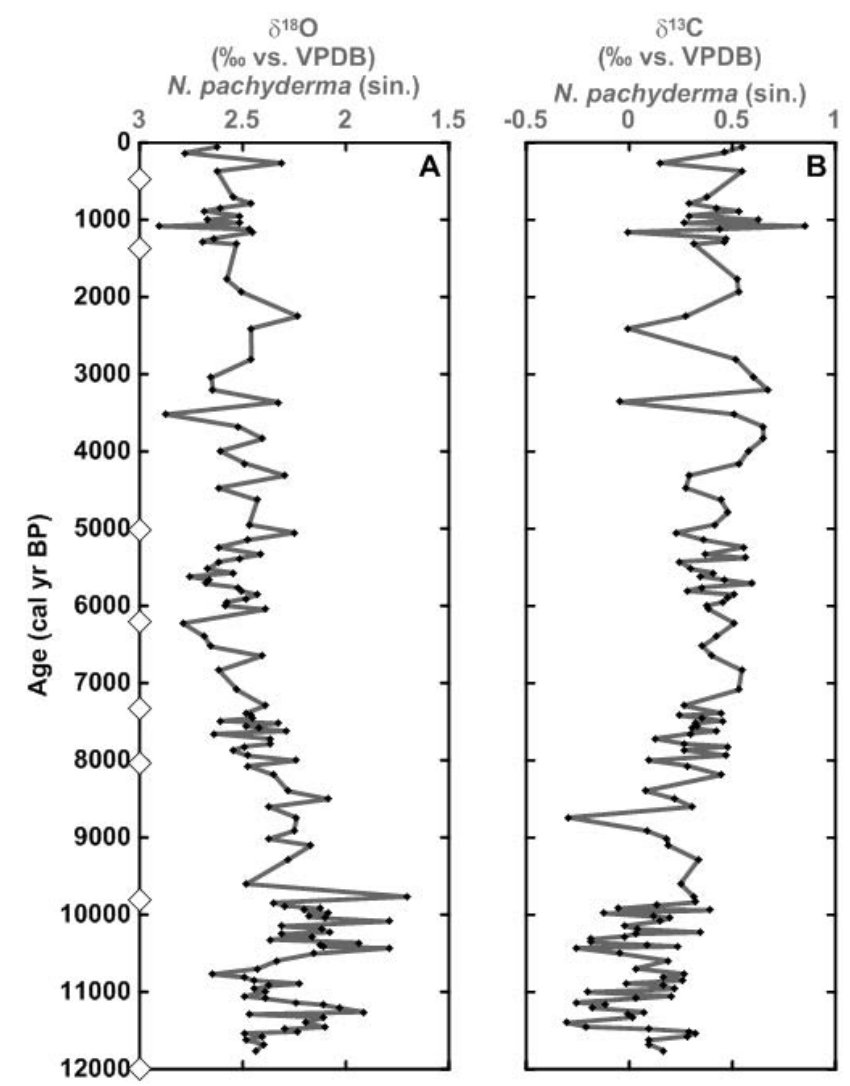

Fig. 5. Stable isotope analysis plotted versus cal yr BP. The white diamonds on the $y$ axis denote the AMS ${ }^{14} \mathrm{C}$ converted to calibrated radiocarbon ages. (A) $\delta^{18} \mathrm{O}$ measurements of $N$. pachyderma (sin.) corrected for ice volume effect after Fairbanks (1989). (B) $\delta^{13} \mathrm{C}$ measurements of $N$. pachyderma (sin.).

The relatively low sSST values $\left(\mathrm{ca} .4^{\circ} \mathrm{C}\right.$ ) throughout this period (Fig. 7 d) are ca. $1.5^{\circ} \mathrm{C}$ lower than modern day temperatures at $100 \mathrm{~m}$ water depth, which argues for an enhanced influence of cold Arctic water at the core site.

Throughout period I, the mean shell weight of $N$. pachyderma (sin.) and the shell fragmentation show the least favourable preservation conditions within the record, likely reflecting increased dissolution (Fig. 7c). The core location is situated above the carbonate compensation depth (CCD); hence, the dissolution must be ascribed to other factors. Dissolution of planktic foraminifera may occur within the water column, at the sediment-water interface and in the sediments (e.g. Lohmann, 1995). Previous research has argued that the dissolution of calcareous material in the Barents Sea is caused by $\mathrm{CO}_{2}$-rich and corrosive bottom water masses (e.g. Steinsund and Hald, 1994), which may be formed by brine rejection in the marginal ice zone (e.g. Midttun, 1985; Steinsund and Hald, 1994). Furthermore, it has been shown that the influence of seasonal sea ice might also affect the preservation conditions (Huber et al., 2000). For example, when organic material at the marginal ice zone sinks unuti- lized to the seafloor, the pore waters become undersaturated with respect to calcium carbonate and can thereby contribute to calcite dissolution (Scott et al., 2008). Hence, the dissolution observed in JM09-KA11-GC may provide evidence for the presence of seasonal sea ice conditions during this interval. Previously, dissolution of planktic foraminifera between 11900 and 9000 cal yr BP was recorded in the central Fram Strait and was attributed to the increased influence of Arctic water, oceanic fronts and the marginal ice zone (Zamelczyk et al., 2012).

The low concentration of planktic foraminifera during this period may also reflect enhanced sea ice conditions (Fig. 7b), especially as areas heavily influenced by sea ice can be almost barren of planktic foraminifera (e.g. Carstens et al., 1997). Previously, a similar low concentration of planktic foraminifera was observed for this period in a core from the south-western Barents Sea, and this was attributed to high sea ice conditions (Aagaard-Sørensen et al., 2010).

Although low $\delta^{13} \mathrm{C}$ values might be associated with poorly ventilated sub-surface water (Sarnthein et al., 1995), the low $\delta^{13} \mathrm{C}$ values during period I could also indicate low primary production consistent with a low concentration of planktic foraminifera (Fig. 7f). On the other hand, the high sterol concentrations and TOC (Fig. 7h, Fig. 6c-e) are more consistent with enhanced primary production, probably reflecting marginal ice zone conditions. Hence, the depleted $\delta^{13} \mathrm{C}$ data more likely suggest a strongly stratified water mass during the early Holocene (period I). This is consistent with previous research from the Barents Sea, where deglaciation processes such as a freshwater influx were suggested to have influenced the top surface water masses (Risebrobakken et al., 2010).

The stable oxygen isotope record in period I shows a general depletion from 11900 to 10400 cal yr BP (Fig. 7e). The sSST increases by ca. $1.5^{\circ} \mathrm{C}$ during this interval, which could explain the depletion (Fig. 7d). However, it has also been shown that the surface water masses in the Barents Sea were also influenced by melt water from the retreating ice sheets during this period (Gyllencreutz et al., 2008; Risebrobakken et al., 2010). Thus, the depleted $\delta^{18} \mathrm{O}$ values most likely reflect both a temperature increase and an influence of melt water causing a surface water freshening in the western Barents Sea.

Throughout period I, there is a progressive decrease in $\mathrm{IP}_{25}$ concentration (and flux), while the profiles of brassicasterol and 24-methylenecholesterol reveal a strong increasing trend (Fig. $7 \mathrm{~g}-\mathrm{h}$ ). These biomarker data likely reflect the abrupt transition from the Younger Dryas into the early Holocene (period I) with an associated reduction in the extent of seasonal sea ice. Previously, a link between enhanced concentrations of 24-methylenecholesterol and sea ice conditions was suggested (Knies, 2005) and later supported by $\mathrm{IP}_{25}$ data (Cabedo-Sanz et al., 2013). However, in the current study, the abundance and flux profiles of 24-methylenecholesterol more closely resemble those of brassicasterol, indicating that 

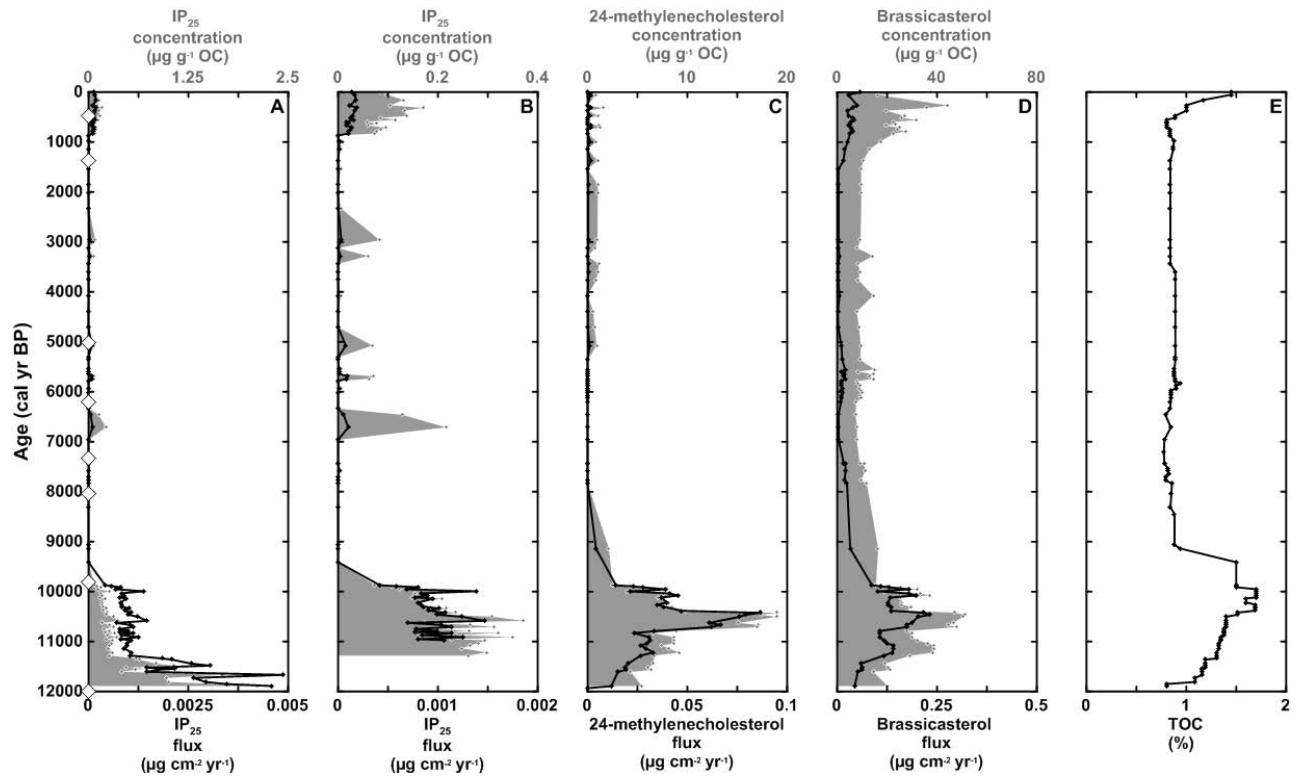

Fig. 6. Biomarker analysis plotted versus cal yr BP. The white diamonds on the $y$ axis denote the AMS ${ }^{14} \mathrm{C}$ converted to calibrated radiocarbon ages. Concentration normalized against organic carbon (grey-filled area) and flux (black line) (note the logarithmic scale for the fluxes): (A) $\mathrm{IP}_{25}$ for the entire record, (B) $\mathrm{IP}_{25}$ since $11300 \mathrm{cal}$ yr BP, (C) 24-methylenecholesterol, (D) brassicasterol and (E) total organic carbon.

24-methylenecholesterol is not as selective a biomarker for sea ice as $\mathrm{IP}_{25}$. Further, the presence of $\mathrm{IP}_{25}$ (albeit in low concentrations) and relatively high concentrations of both sterols, especially between ca. 10800 and 10300 cal yr BP, suggests that during the early Holocene, the study area was probably characterized by periods of sea ice edge conditions or close to the marginal ice zone, since this scenario results generally in enhanced primary production (Smith et al., 1985; Sakshaug, 1997). At the same time, sSST values increase rapidly, whereas $\delta^{18} \mathrm{O}$ values are depleted, all showing a surface warming which corresponds to previous research in the region (e.g. Sarnthein et al., 2003; Rasmussen et al., 2007; Risebrobakken et al., 2010). However, a depletion in $\delta^{18} \mathrm{O}$ during this interval for the south-western Barents Sea has also been suggested to reflect surface water freshening caused by seasonal sea ice melting (Aagaard-Sørensen et al., 2010).

Within period I, six data points between 10900 and $10700 \mathrm{cal}$ yr BP show a rapid and large increase of $N$. pachyderma (sin.) corresponding to a cooling of ca. $2.5^{\circ} \mathrm{C}$ (Figs. 7a, d). Simultaneously, a rapid $\delta^{18} \mathrm{O}$ enrichment occurs which also reflects this cooling signal (Fig. 7e). Although this abrupt cooling signal is not recorded by the biomarker or $\delta^{13} \mathrm{C}$ data, it seems to reflect and coincide with the socalled Preboreal Oscillation (PBO). The PBO has previously been recorded throughout the North Atlantic region in different proxy records such as ice core (e.g. Johnsen et al., 1995), terrestrial (e.g. Becker et al., 1991; Björck et al., 1996) and marine palaeo-records (e.g. Hald and Hagen, 1998; Husum and Hald, 2002), and was probably triggered by a melt water outburst hampering the thermohaline convection in the North Atlantic (Björk et al., 1996; Hald and Hagen, 1998; Husum and Hald, 2002).

\subsection{Period II: 10 400-7300 cal yr BP (early-mid-Holocene)}

The gradual and steady increase of $T$. quinqueloba from 10400 to 9900 and from 9900 to 7300 cal yr BP, respectively, suggests a change in water masses from Arctic to Atlantic water (Fig. 4b). Previously, Werner et al. (2013) also attributed a high relative abundance of $T$. quinqueloba to a strong influence of Atlantic water during this period.

T. quinqueloba is associated with sub-polar conditions and Atlantic water (Bé and Tolderlund, 1971; Volkmann, 2000). Furthermore, high abundances of T. quinqueloba (> 80\%) have been found in close proximity to the sea ice margin in the eastern Fram Strait and northern Barents Sea (Volkmann, 2000). This species responds rapidly to changes in nutrient supply (Reynolds and Thunnel, 1985; Johannessen et al., 1994) and is associated with oceanic front conditions. In the western Barents Sea, it has also been associated with the Arctic front (Burhol, 1994).

Werner et al. (2013) also made a link between high planktic foraminiferal fluxes and ice-free conditions or a fluctuating (seasonal) sea ice margin. Further, $N$. incompta also indicates an increased influence of warmer Atlantic water during period II as it reaches its maximum abundance within the record at the beginning of this interval (Fig. 4c). N. incompta is a warm-water indicator, often associated with the inflow of temperate Atlantic water (Bé and Tolderlund, 1971; 


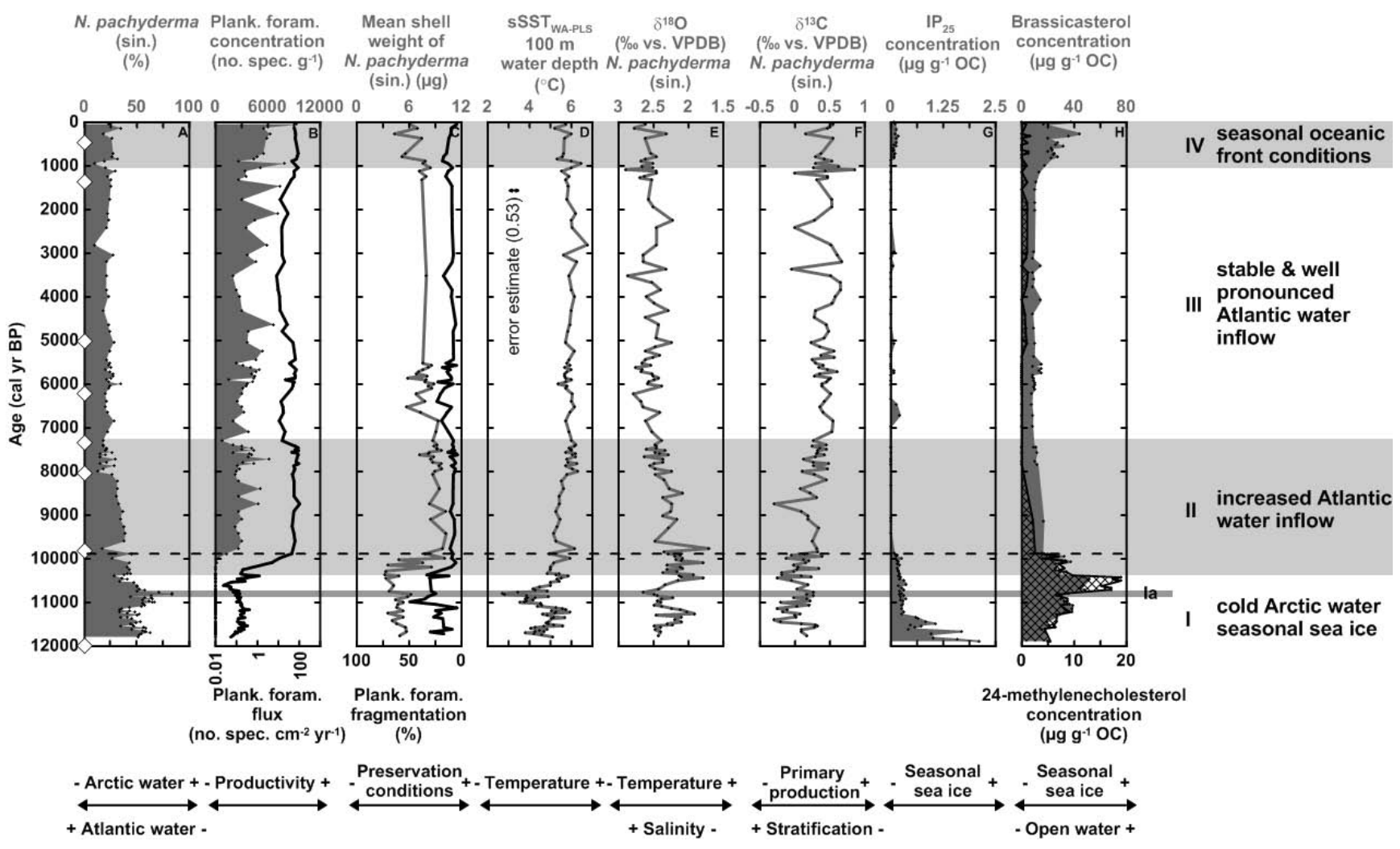

Fig. 7. Summary and palaeoceanographic development interpretation of multi-proxy data plotted versus cal yr BP. The white diamonds on the $y$ axis denote the AMS ${ }^{14} \mathrm{C}$ converted to calibrated radiocarbon ages. Samples below the dotted line contain $<300$ planktic foraminiferal specimens. (A) Relative abundance of $N$. pachyderma (sin.). (B) Planktic foraminiferal concentration (grey-filled area) and total planktic foraminiferal flux (black line) (note the logarithmic scale for the flux). (C) Mean shell weight of N. pachyderma (sin.) (grey line) and planktic foraminiferal fragmentation (black line) (note the reversed axis). (D) Reconstructed summer sea surface temperature estimates. (E) $\delta^{18} \mathrm{O}$ measurements of $N$. pachyderma ( sin.) corrected for ice volume effect after Fairbanks (1989). (F) $\delta^{13} \mathrm{C}$ measurements of $N$. pachyderma (sin.). (G) Seasonal sea ice biomarker $\mathrm{IP}_{25}$ concentration normalized against organic carbon. (H) Sterol concentration normalized against organic carbon: brassicasterol (grey-filled area) and 24-methylenecholesterol (black-hatched area).

Johannessen et al., 1994; Pflaumann et al., 2003). A similar maximum of N. incompta (ca. $20 \%$ ) has been observed in previous studies between ca. 9000 and $10500 \mathrm{cal} \mathrm{yr} \mathrm{BP}$ in the western Barents Sea and western Svalbard margin (Sarnthein et al., 2003; Ebbesen et al., 2007; Hald et al., 2007). This relatively high abundance of $N$. incompta (before dropping to ca. $10 \%$ towards the mid-late Holocene (period III)) might reflect the previously described Holocene Climate Optimum, which is linked to the increased June solar insolation at high latitudes (e.g. Koç et al., 1993; Kaufman et al., 2004; Hald et al., 2007). However, the sSST record shows a small warming trend, reaching ca. $6^{\circ} \mathrm{C}$ around $8000 \mathrm{cal} \mathrm{yr} \mathrm{BP}$ and remains relatively stable for the rest of the Holocene (Fig. 7d). This temperature trend may simply reflect stability in the temperature of the sub-surface water masses and that only the upper surface layers reflect the solar maximum, as suggested by Andersson et al. (2010). However, the reconstructed SSST also reflects the planktic foraminiferal fauna data, which differ from previous studies in the region with its very high abundance of T. quinqueloba (e.g. Sarnthein et al., 2003;
Ebbesen et al., 2007; Hald et al., 2007; Risebrobakken et al., 2010). The current study site may be closer to the Arctic front compared to other studies, which may explain the differences in fauna between studies (e.g. Johannessen et al., 1994), although these could also be related to the state of preservation.

From 10400 to 9900 cal yr BP, the increased shell weight and concomitant decrease in fragmentation indicate a sharp improvement in preservation conditions (Fig. 7c), a feature that was also observed between 10800 and $8000 \mathrm{cal} \mathrm{yr} \mathrm{BP}$ in the western Fram Strait (Zamelczyk et al., 2012). Generally good preservation conditions have been linked to Atlantic surface water where the organic matter productivity is lower, the rain of $\mathrm{CaCO}_{3}$ higher and thus the pore waters supersaturated with respect to calcium (Huber et al., 2000; Henrich et al., 2002). Further, according to Edmond and Gieskes (1970), the solubility of $\mathrm{CaCO}_{3}$ increases with decreasing temperatures and increasing salinities and concentrations of $\mathrm{CO}_{2}$. However, the solubility is also influenced by pressure and thus the water depth of a core site (Archer and Maier-Reimer, 1994). The latter may explain why the dissolution indices 
show generally very good preservation conditions for this core site as the water depth is only $345 \mathrm{~m}$.

Dissolution, however, may be selective and is known to affect small species such as T. quinqueloba to a greater extent than more resistant thick-shelled species, thus changing the species composition of a foraminiferal assemblage (e.g. Berger, 1970; Thunell and Honjo, 1981; Le and Thunell, 1996). As such, the increased relative abundance of T. quinqueloba and the clear increase in total planktic foraminiferal concentrations and fluxes from ca. 10400 to 9900 cal yr BP may be partially attributed to selective preservation. This selective dissolution might have potential implications for the transfer-function-derived sSST as these depend on the composition of foraminiferal assemblages.

The $\delta^{13} \mathrm{C}$ values increase continuously throughout the early-mid-Holocene, arguing for a gradual evolution in better-ventilated surface water and/or enhanced primary production (Fig. 7f). The increasing $\delta^{18} \mathrm{O}$ record suggests increased salinities and/or decreasing temperatures, although the planktic foraminiferal data do not indicate any changes in temperature (Fig. 7e). This increase in salinity is most likely caused by an increased Atlantic water inflow, which supports earlier observations for this time interval (e.g. Risebrobakken et al., 2010).

In terms of the biomarker data, previous studies have shown a strong positive correlation between the presence of $\mathrm{IP}_{25}$ and regions of known seasonal sea ice cover, while, temporally, directional changes in $\mathrm{IP}_{25}$ are normally consistent with corresponding changes in seasonal sea ice extent (Belt and Müller, 2013). Therefore, the declining trend in $\mathrm{IP}_{25}$ concentrations from period I, before disappearing from the record at ca. 9900 cal yr BP (Fig. 7g), is consistent with progressively reduced seasonal sea ice. At the same time, brassicasterol concentrations also reduce, likely reflecting the transitions from a favourable marginal ice zone scenario (c.f. period I) to reduced seasonal sea ice cover and finally open water conditions, which are less productive (Fig. 7h).

Thus, the proxy data identify changing water masses, with a steady increase of Atlantic water inflow in particular. Nonetheless, despite the gradual increase of Atlantic water inflow, Arctic front conditions and the presence of seasonal sea ice remains in the proximity of the core site, at least until ca. 9900 cal yr BP. Previous studies from the Barents Sea have recorded similar oceanic front conditions as well as an inflow of sub-surface Atlantic water during the early Holocene (e.g. Lubinski et al., 1996; Hald et al., 1999; Duplessy et al., 2005; Risebrobakken et al., 2010). The most likely north-eastwards shift of oceanic front conditions throughout the early Holocene has been linked to positive NAO index values, with an increase to the inflow of Atlantic water to the North Atlantic and Barents Sea (e.g. AagaardSørensen et al., 2010).

\subsection{Period III: 7300-1100 cal yr BP (mid-late Holocene)}

The faunal composition in period III is marked by relatively consistent abundances of all species and a distinct dominance of T. quinqueloba (ca. $60 \%$ ), possibly suggesting a stable influence of Atlantic water. However, as discussed previously for period II, the high abundance of T. quinqueloba differs from earlier published records from this area (e.g. Sarnthein et al., 2003; Hald et al., 2004, 2007; Ebbesen et al., 2007; Werner et al., 2013), which might reflect regional oceanographic differences such as a more general proximity to the Arctic front in the Barents Sea (e.g. Volkmann, 2000; Husum and Hald, 2012). The sea ice biomarker $\mathrm{IP}_{25}$ is mainly absent throughout the mid-late Holocene, reflecting predominantly ice-free ocean conditions (Fig. $7 \mathrm{~g}-\mathrm{h}$ ), meaning that the marginal ice zone was not at the core site. In contrast, increased $\mathrm{IP}_{25}$ concentrations (and hence inferred sea ice conditions) were observed for the West Spitsbergen Shelf during the same interval (Müller et al., 2012), likely reflecting the differences (latitude) between the two study locations.

Although the mean shell weight is slightly lower in period III compared to period II, the preservation indicators are stable throughout the mid-late Holocene (Fig. 7c), which indicates a continuation of the more favourable preservation conditions, most likely linked to the shallow water depth and presence of Atlantic water.

The stability in the relative abundances of the foraminifera is accompanied by a stable sSST record throughout the midlate Holocene (Fig. 7d). This contrasts earlier reconstructions of SST based on diatoms (Koç et al., 1993) and alkenones (Calvo et al., 2002), which showed a cooling trend throughout the mid-late Holocene. This difference in outcomes might be due to the fact that surface cooling (or warming) that results from variability in insolation may be mainly restricted to the upper ca. $30 \mathrm{~m}$ of the water column (Andersson et al., 2010; Risebrobakken et al., 2011). Nonetheless, previous studies of planktic foraminifera in the region have also identified a cooling during the mid-late Holocene (e.g. Sarnthein et al., 2003; Werner et al., 2013). For example, sediment core T88-2 in the south-western Barents Sea showed a less pronounced optimum ending at $6300 \mathrm{cal}$ yr BP, while sediment core MD99-2304 at the western Svalbard margin has a clear optimum ending at 8600 cal yr BP (Ebbesen et al., 2007; Hald et al., 2007; Husum and Hald, 2012). These differences are most likely due to the different study locations reflecting different water masses and settings. The SST reconstructions based on foraminiferal transfer functions do not reflect any changes of nutrition. T. quinqueloba depends on somewhat warmer and/or nutritious water masses (e.g. Volkmann, 2000), and hence a minor cooling signal may not be reflected if the nutrition is unchanged.

In general, the planktic foraminiferal concentrations and fluxes remain stable throughout the mid-late Holocene, suggesting that the environmental conditions remained relatively stable and favourable for planktic foraminifera throughout 
this period. The consistent $\delta^{13} \mathrm{C}$ data between 7300 and $1100 \mathrm{cal}$ yr BP indicate less stratified water masses compared to the early and early-mid-Holocene, probably due to a single, well-mixed Atlantic water mass (Fig. 7f). Together with the relative warm and stable sSST values, the $\delta^{18} \mathrm{O}$ record most likely reflects stable and high salinities throughout the mid-late Holocene and thereby indicates a stable and strong Atlantic water inflow, consistent with the outcomes from other records (e.g. Risebrobakken et al., 2010) (Fig. 7e).

\subsection{Period IV: 1100-0 cal yr BP (late Holocene-present)}

During the last $1100 \mathrm{cal} y \mathrm{BP}$, the planktic foraminiferal fauna changes slightly compared to period III, showing a minor increase of G. glutinata and a larger increase of $G$. uvula (Fig. 4d, e). The cosmopolitan species G. glutinata has also been associated with warm-water masses (Hemleben et al., 1989). G. uvula is a high-latitude species indicative of a high food supply and high abundances are associated with the productive zone connected with oceanic fronts (Saito et al., 1981; Boltovskoy et al., 1996; Bergami et al., 2009). Further, G. uvula is also connected with slightly reduced salinities and is found in high numbers in the coastal water in the south-western Barents Sea (Husum and Hald, 2012).

The sSST and $\delta^{18} \mathrm{O}$ values might indicate a minor cooling in this period; however, the mean values are only $5.7^{\circ} \mathrm{C}$ and $-0.23 \%$ o compared to $5.9^{\circ} \mathrm{C}$ and $-0.20 \%$ in the preceding period (Fig. $7 \mathrm{~d}$, e). The $\delta^{18} \mathrm{O}$ values may also indicate a minor increase in salinity, but the planktic foraminiferal fauna very clearly shows slightly lower salinities in the sub-surface waters at this time. This corresponds well with previous findings that have shown a reduced salinity or freshening of the uppermost surface layer with concomitant increases in sea ice conditions during the past ca. $3000 \mathrm{cal}$ yr BP in the Fram Strait (Werner et al., 2013). Additionally, a reduced salinity in the upper water masses was also observed between 2500 and 0 cal yr BP in the southern Barents Sea (Risebrobakken et al., 2010). However, Risebrobakken et al. (2010) further found that the episodes of reduced salinity were also associated with lower temperatures, which is not seen clearly in the current study. The fluctuating absence and presence of $\mathrm{IP}_{25}$ (at very low concentrations) and increasing brassicasterol concentrations during the last ca. $1100 \mathrm{cal}$ yr BP suggests that this area experienced sea ice conditions, with alternating periods of ice-free conditions and low occurrences of seasonal sea ice close to the core site (Fig. 7g-h). A similar observation of frequently fluctuating sea ice conditions was made by Müller et al. (2012) for the West Spitsbergen Shelf, although these conditions were observed after ca. $3000 \mathrm{cal}$ yr BP. Such conditions are similar to those of the present day, based on satellite imagery and biomarker reconstructions (NavarroRodriguez et al., 2013).

The occurrence of seasonal sea ice may also explain the decreased mean shell weight of $N$. pachyderma (sin.) as a result of some dissolution; however the fragmentation remains relatively stable (Fig. 7c). The dissolution is probably caused by the presence of sea ice as seasonal sea ice might also affect the preservation conditions (e.g. Huber et al., 2000).

The planktic foraminiferal concentration reaches its maximum value of the entire record during this period (Fig. 7b) and, together with the slightly enriched $\delta^{13} \mathrm{C}$ values (Fig. 7f), indicates higher primary productivity associated with the oceanic front conditions. The $\delta^{13} \mathrm{C}$ values could also reflect more stratified water masses due to a decreased influence of Atlantic water. Nonetheless, the sSST and $\delta^{18} \mathrm{O}$ values do not show a clear cooling, which could indicate a reduced inflow of Atlantic water. Other proxies - such as coccoliths, benthic foraminifera, benthic stable isotopes $\left(\delta^{18} \mathrm{O}\right)$ and grain size analysis - have also been investigated within the current sediment core. These show relatively stable temperatures in addition to suggesting an increased inflow of Atlantic water to the core site during this time interval (Dylmer et al., 2013; Groot et al., 2013), hence providing further evidence for stratification of the upper water column.

The sSST and planktic $\delta^{18} \mathrm{O}$ values from the current study do not show the same cooling trend of the surface water masses during the late Holocene as found by others in the eastern Nordic Seas (e.g. Koç et al., 1993; Calvo et al., 2002; Risebrobakken et al., 2010), although it is noted that Arctic planktic foraminifera may not reflect the decreasing insolation due to their depth habitat (Andersson et al., 2010; Risebrobakken et al., 2011). The reappearance of some seasonal sea ice may be attributed to decreasing insolation, which may have caused more severe winter and sea ice conditions and hence increasing the seasonal difference. In support of this, Jernas et al. (2013) have also observed a stronger influence of seasonal (spring/summer) inflow of Atlantic water at this time at the western Svalbard margin. Werner et al. (2013) also suggest a slight re-strengthening of Atlantic water inflow based on their SST record after ca. 3000 cal yr BP, while they also observe an increase of sea ice conditions.

\section{Conclusions}

This paper presents a multi-proxy study of sub-surface and sea ice conditions in the western Barents Sea throughout the Holocene.

The early Holocene (11 900-10 400 cal yr BP) was characterized by cold water and a reduced Atlantic water inflow. The planktic foraminiferal fauna is dominated by the polar species $N$. pachyderma $(\sin$.) and the sSST values were found to be around $4^{\circ} \mathrm{C}$. Stable oxygen isotope values are ca. $-0.75 \%$, reflecting a surface freshening. The core site was also characterized by the transition from severe sea ice conditions at the termination of the Younger Dryas to a marginal ice zone scenario that was favourable for primary production.

Within the early Holocene, a short-term cooling event is shown by both the planktic fauna and the stable isotopes from $10900-10700 \mathrm{cal}$ yr BP and is correlated with the so-called 
Preboreal Oscillation, which is found throughout the North Atlantic region.

During the early-mid-Holocene (10 400-7300 cal yr BP), Atlantic water inflow increases as shown by planktic foraminiferal fauna dominated by $T$. quinqueloba and enriched $\delta^{18} \mathrm{O}$ values reflecting increased salinity. Biomarkers indicate a decline in seasonal sea ice extent and the sSST record reaches values of $6^{\circ} \mathrm{C}$ at ca. $8000 \mathrm{cal} \mathrm{yr} \mathrm{BP}$ and remains relatively stable for the rest of the record.

Throughout the mid-late Holocene (7300-1100 cal yr BP), environmental conditions are stable with a pronounced inflow of Atlantic water with relatively warm sub-surface temperatures around $5.9^{\circ} \mathrm{C}$, predominantly ice-free conditions and $\delta^{18} \mathrm{O}$ values reflecting stable high salinities.

Within the late Holocene (1100-0 cal yr BP), the planktic foraminiferal fauna changes slightly, with a higher abundance of G. uvula showing a reduced salinity. The sSST and $\delta^{18} \mathrm{O}$ values may indicate a very minor cooling, but overall the values do not decrease compared to the mid-late Holocene. The presence of $\mathrm{IP}_{25}$, in particular, suggests a reappearance of low-frequency seasonal sea ice. In general, all proxies from this period fluctuate rapidly, indicating more unstable oceanographic conditions.

Acknowledgements. This work was carried out within the framework of the Initial Training Network programme "Changing Arctic and Subarctic Environment" (CASE, grant agreement no. 238111) funded by the European Commission within the 7 th Framework Programme FP7 2007/2013, Marie-Curie Actions and the University of Troms $\emptyset$. Further, the project "Glaciations in the Barents Sea Area" (GlaciBar) funded by the Research Council of Norway, Statoil, Det Norske, British Gas and the University of Troms $\emptyset$ is acknowledged for providing the marine sediment core and CTD data from the core site. Jan P. Holm helped prepare the maps. Thanks are also extended to one anonymous reviewer and Juliane Müller for their helpful and informative reviews.

Edited by: J. Knies

\section{References}

Aagaard-Sørensen, S., Husum, K., Hald, M., and Knies, J.: Paleoceanographic development in the SW Barents Sea during the Late Weichselian-Early Holocene transition, Quaternary Sci. Rev., 29, 1-15, 2010.

Andersen, C., Koç, N., Jennings, A. E., and Andrews, J. T.: Nonuniform response of the major surface currents in the Nordic Seas to insolation forcing: implications for the Holocene climate variability, Paleoceanography, 19, PA2003, doi:10.1029/2002PA000873, 2004.

Andersson, C., Risebrobakken, B., Jansen, E., and Dahl, S.O.: Late Holocene surface ocean conditions of the Norwegian Sea (Vöring Plateau), Paleoceanography, 18, 1044, doi:10.1029/2001PA000654, 2003.

Andersson, C., Pausata, F. S. R., Jansen, E., Risebrobakken, B., and Telford, R. J.: Holocene trends in the foraminifer record from the Norwegian Sea and the North Atlantic Ocean, Clim. Past, 6, 179-193, doi:10.5194/cp-6-179-2010, 2010.

Archer, D.: A data-driven model of the global calcite lysocline, Global Biogeochem. Cy., 10, 511-526, 1996.

Archer, D. and Maier-Reimer, E.: Effect of deep-sea sedimentary calcite preservation on atmospheric $\mathrm{CO}_{2}$ concentration, Nature, 367, 260-263, 1994.

Aure, J. and Strand, Ø.: Hydrographic normals and long-term variations at fixed surface layer stations along the Norwegian coast from 1936 to 2000, Fisken og Havet, 13, 1-24, 2001.

Barker, S. and Elderfield, H.: Foraminiferal calcification response to glacial interglacial changes in atmospheric $\mathrm{CO}_{2}$, Science, 297, 883-836, 2002.

Barker, S., Kiefer, T., and Elderfield, H.: Temporal changes in North Atlantic circulation constrained by planktonic foraminiferal shell weights, Paleoceanography, 19, PA3008, doi:10.1029/2004PA001004, 2004.

Bauch, H. A. and Weinelt, M. S.: Surface water changes in the Norwegian Sea during last deglacial and Holocene times, Quaternary Sci. Rev., 16, 1115-1124, 1997.

Bé, A. W. H. and Tolderlund, D. S.: Distribution and ecology of living planktonic foraminifera in surface waters of the Atlantic and Indian Oceans, in: The micropaleontology of oceans, edited by: Funnel, B. M. and Riedel, W. R., Cambridge University Press, London, 1-100, 1971.

Becker, B., Kromer, B., and Trimborn, P.: A stable isotope tree-ring timescale of the Late Glacial/Holocene boundary, Nature, 353 , 647-649, 1991.

Beer, C. J., Schiebel, R., and Wilson, P. A.: Testing planktic foraminiferal shell weight as a surface water $\left[\mathrm{CO}_{3}^{2-}\right]$ proxy using plankton net samples, Geology, 38, 103-106, 2010.

Belt, S. T. and Müller, J.: The Arctic sea ice biomarker $\mathrm{IP}_{25}$ : a review of current understanding, recommendations for future research and applications in palaeo sea ice reconstructions, Quaternary Sci. Rev., 79, 9-25, doi:10.1016/j.quascirev.2012.12.001, 2013.

Belt, S. T., Masseé, G., Rowland, S. J., Poulin, M., Michel, C., and LeBlanc, B.: A novel chemical fossil of palaeo sea ice: $\mathrm{IP}_{25}$, Org. Geochem., 38, 16-27, 2007.

Belt, S. T., Brown, T. A., Navarro Rodriguez, A., Cabedo Sanz, P., Tonkin, A., and Ingle, R.: A reproducible method for the extraction, identification and quantification of the Arctic sea ice proxy $\mathrm{IP}_{25}$ from marine sediments, Anal. Method., 4, 705-713, 2012.

Bergami, C., Capotondi, L., Langone, L., Giglio, F., and Ravaioli, M.: Distribution of living planktonic foraminifera in the Ross Sea and the Pacific sector of the Southern Ocean (Antarctica), Mar. Micropaleontol., 73, 37-48, 2009.

Berger, A.: Long-term variations of daily insolation and quaternary climatic changes, J. Atmos. Sci., 35, 2363-2367, 1978.

Berger, W. H.: Planktonic foraminifera: Selective solution and the lysocline, Mar. Geol., 8, 111-138, 1970.

Birks, H. J. B.: Quantitative palaeoenvironmental reconstructions, in: Statistical modelling of quaternary science data, edited by: Maddy, D. and Brew, J. S., Quaternary Research Association, Cambridge, UK, 116-254, 1995.

Birks, C. J. A. and Koç, N.: A high-resolution diatom record of late-quaternary sea-surface temperatures and oceanographic conditions from the eastern Norwegian Sea, Boreas, 31, 323-344, 2002 . 
Björck, S., Kromer, B., Johnsen, S., Bennike, O., Hammarlund, D., Lemdahl, G., Possnert, G., Rasmussen, T. L., Wohlfarth, B., Hammer, C. U., and Spurk, M.: Synchronized terrestrial atmospheric deglacial records around the North Atlantic, Science, 274, 1155-1160, 1996.

Blindheim, J.: The seas of Norden, in: Norden: Man and environment, edited by: Varjo, U. and Tietze, W., Gebrüder Borntraeger, Berlin, 20-32, 1987.

Boltovskoy, E., Boltovskoy, D., Correa, N., and Brandini, F.: Planktic foraminifera from the southwestern Atlantic $\left(30^{\circ}-60^{\circ} \mathrm{S}\right)$ : Species-specific patterns in the upper $50 \mathrm{~m}$, Mar. Micropaleontol., 28, 53-72, 1996.

Bond, G., Showers, W., Cheseby, M., Lotti, R., Almasi, P., deMenocal, P., Priore, P., Cullen, H., Hajdas, I., and Bonani, G.: A pervasive millennial-scale cycle in North Atlantic Holocene and glacial climates, Science, 278, 1257-1266, 1997.

Broecker, W. S.: The great ocean conveyor. Oceanography, 4, 7989, 1991.

Broecker, W. S. and Clark, E.: An evaluation of Lohmann's foraminifera weight dissolution index, Paleoceanography, 16, 531-534, 2001.

Brown, T. A. and Belt, S. T.: Identification of the sea ice diatom biomarker $\mathrm{IP}_{25}$ in Arctic benthic macrofauna: Direct evidence for a sea ice diatom diet in Arctic heterotrophs, Polar Biol., 35, 131-137, 2012.

Brown, T. A., Belt, S. T., Philippe, B., Mundy, C. J., Massé, G., Poulin, M., and Gosselin, M.: Temporal and vertical variations of lipid biomarkers during a bottom ice diatom bloom in the Canadian Beaufort Sea: Further evidence for the use of the $\mathrm{IP}_{25}$ biomarker as a proxy for spring Arctic sea ice, Polar Biol., 34, 1857-1868, 2011.

Burhol, A. L. S.: Recent distribution of planktonic foraminifera on the Svalbard-Barents margin, Master Thesis, University of Troms $\varnothing$, Norway, 1994.

Cabedo-Sanz, P., Belt, S. T., Knies, J., and Husum, K: Identification of contrasting seasonal sea ice conditions during the Younger Dryas, Quaternary Sci. Rev., 79, 74-86, 2013.

Calvo, E., Grimalt, J., and Jansen, E.: High resolution $\mathrm{U}_{K}^{37}$ sea surface temperature reconstruction in the Norwegian Sea during the Holocene, Quaternary Sci. Rev., 21, 1385-1394, 2002.

Carstens, J., Hebbeln, D., and Wefer, G.: Distribution of planktic foraminifera at the ice margin in the Arctic (Fram Strait), Mar. Micropaleontol., 29, 257-269, 1997.

Cifelli, R.: Globigerina incompta, a new species of pelagic foraminifera from the North Atlantic, Contributions Cushman Foundation Foraminiferal Research, 12, 83-86, 1961.

Comiso, J. C., Parkinson, C. L., Gersten, R., and Stock, L.: Accelerated decline in the Arctic sea ice cover, Geophys. Res. Lett., 35, L01703, doi:10.1029/2007GL031972, 2008.

Conan, S. M. H., Ivanova, E. M., and Brummer, G. J. A.: Quantifying carbonate dissolution and calibration of foraminiferal dissolution indices in the Somali Basin, Mar. Geol., 182, 325-349, 2002.

Darling, K. F., Kucera, M., Kroon, D., and Wade, C. M.: A resolution for the coiling direction paradox in Neogloboquadrina pachyderma, Paleoceanography, 21, PA2011, doi:101029/2005PA001189, 2006.

Dieckmann, G. S. and Hellmer, H. H.: The importance of sea ice: An overview, in: Sea ice: An introduction to its physics, chemistry, biology and geology, edited by: Thomas, D. N. and Dieckmann, G. S., Blackwell Science Ltd, Oxford, UK, doi:10.1002/9780470757161.ch1, 2008.

Duplessy, J. C., Ivanova, E., Murdmaa, I., Paterne, M., and Labeyrie, L.: Holocene paleoceanography of the northern Barents Sea and variations of the northward heat transport by the Atlantic Ocean, Boreas, 30, 2-16, 2001.

Duplessy, J. C., Cortijo, E., Ivanova, E., Khusid, T., Labeyrie, L., Levitan, M., Murdmaa, I., and Paterne, M.: Paleoceanography of the Barents Sea during the Holocene, Paleoceanography, 20, A4004, doi:10.1029/2004PA001116, 2005.

Dylmer, C. V., Giraudeau, J., Eynaud, F., Husum, K., and De Vernal, A.: Northward advection of Atlantic water in the eastern Nordic Seas over the last $3000 \mathrm{yr}$ : A coccolith investigation of volume transport and surface water changes, Clim. Past, 9, 1505-1518, doi:10.5194/cp-9-1505-2013, 2013.

Ebbesen, H., Hald, M., and Eplet, T. H.: Late glacial and early Holocene climatic oscillations on the western Svalbard margin, European Arctic, Quaternary Sci. Rev., 26, 1999-2011, 2007.

Edmond, J. M. and Gieskes, T. M.: On the calculation of the degree of saturation of sea water with respect to calcium carbonate under in situ conditions, Geochim. Cosmochim. Acta, 35, 1261-1291, 1970.

Ehrmann, W. U. and Thiede, J.: History of Mesozoic and Cenozoic sediment fluxes to the North Atlantic Ocean, Contributions to Sedimentology E. Schweizerbart'sche Verlagsbuchhandlung, Stuttgart, 15, 1-109, ISBN 3-510-57015-4, 1985.

Eynaud, F.: Planktonic foraminifera in the Arctic: Potentials and issues regarding modern and quaternary populations, IOP Conf. Series: Earth and Environmental Science, 14, 2011.

Fairbanks, R. G.: A 17 000-year glacia-eustatic sea level record: Influence of glacial melting rates on the Younger Dryas event and deep-ocean circulation, Nature, 342, 637-642, 1989.

Francis, J. A., Chan, W., Leathers, D. J., Miller, J. R., and Veron, D. E.: Winter Northern Hemisphere weather patterns remember summer Arctic sea-ice extent, Geophys. Res. Lett., 36, L07503, doi:10.1029/2009GL037274, 2009.

Giraudeau, J., Jennings, A. E., and Andrews, J. T.: Timing and mechanisms of surface and intermediate water circulation changes in the Nordic seas over the last 10,000 cal years: A view from the north Iceland shelf, Quaternary Sci. Rev., 23, 212-72139, 2004.

Goosse, H. and Holland, M.: Mechanisms of decadal and interdecadal Arctic variability in the Community Climate System Model CCSM2, J. Climate, 18, 3552-3570, 2005.

Groot, D. E., Aagaard-Sørensen, S., and Husum, K.: Reconstruction of Atlantic Water variability during the Holocene in the western Barents Sea, Clim. Past Discuss., 9, 4293-4322, doi:10.5194/cpd-9-4293-2013, 2013.

Gyllencreutz, R., Mangerud, J., Svendsen, J. I., and Lohne, Ø.: Reconstructing growth and decay of the Eurasian ice sheet during the Late Weichselian, 33rd International Geological Congress (33IGC), 6-14 August 2008, HPQ01805L, available at: http: //www.cprm.gov.br/33IGC/1345819.html, 2008.

Hald, M. and Hagen, S.: Early preboreal cooling in the Nordic Sea region triggered by meltwater, Geology, 26, 615-618, 1998.

Hald, M., Kolstad, V., Polyak, L., Forman, S. L., Herlihy, F. A., Ivanov, G., and Nesheretov, A.: Late-glacial and Holocene paleoceanography and sedimentary environments in the St. Anna 
trough, Eurasian Arctic Ocean margin, Paleoceanography, Paleoclimatology, Palaecology, 146, 229-249, 1999.

Hald, M., Ebbesen, H., Forwick, M., Godtliebsen, F., Khomenko, L., Korsun, S., Ringstad Olsen, L., and Vorren, T. O.: Holocene paleoceanography and glacial history of the West Spitsbergen area, Euro-Arctic margin, Quaternary Sci. Rev., 23, 2075-2088, 2004.

Hald, M., Andersson, C., Ebbesen, H., Jansen, E., KlitegaardKristensen, D., Risebrobakken, B., Salomonsen, G. R., Sejrup, H. P., Sarnthein, M., and Telford, R.: Variations in temperature and extent of Atlantic water in the northern North Atlantic during the Holocene, Quaternary Sci. Rev., 26, 3423-3440, 2007.

Hemleben, C., Spindler, M., and Anderson, O. R.: Modern planktonic foraminifera, Springer, New York, 363 pp., 1989.

Henrich, R., Baumann, K. H., Huber, R., and Meggers, H.: Carbonate preservation records of the past $3 \mathrm{Myr}$ in the NorwegianGreenland Sea and the northern North Atlantic: Implications for the history of NADW production, Mar. Geol., 184, 17-39, 2002.

Hopkins, T. S.: The GIN Sea: A synthesis of its physical oceanography and literature review, 1972-1985, Earth Sci. Rev., 30, 175318, 1991.

Huber, R., Meggers, H., Baumann, K. H., and Henrich, R.: Recent and Pleistocene carbonate dissolution in sediments of the Norwegian-Greenland Sea, Mar. Geol., 165, 123-136, 2000.

Husum, K. and Hald, M.: Early Holocene cooling events in Malangenfjord and the adjoining shelf, north-east Norwegian Sea, Polar Res., 21, 267-274, 2002.

Husum, K. and Hald, M.: A continuous marine record 8000-1600 cal. yr BP from the Malangenfjord, north Norway: Foraminiferal and isotopic evidence, Holocene, 14, 877-887, 2004.

Husum, K. and Hald, M.: Arctic planktic foraminiferal assemblages: Implications for subsurface temperature reconstructions, Mar. Micropaleontol., 96-97, 38-47, 2012.

Imbrie, J. and Kipp, N. G.: A new micropaleontological method for quantitative paleoclimatology: Applications to a late Pleistocene Caribbean core, in: Late Cenozoic Glacial Ages, edited by: Turkian, K. K., Yale University Press, New Haven, 71-191, 1971.

Jennings, A., Knudsen, K. L., Hald, M., Hansen, C. V., and Andrews, J. T.: A mid-Holocene shift in Arctic sea-ice variability on the East Greenland shelf, Holocene, 12, 49-58, 2002.

Jernas, P., Klitgaard Kristensen, D., Husum, K., Wilson, L., and Koç, N.: Palaeoenvironmental changes of the last two millennia on the western and northern Svalbard shelf, Boreas, 42, 236-255, 2013.

Jiang, H., Seidenkrantz, M. S., Knudsen, K. L., and Eiriksson, J.: Late-Holocene summer sea-surface temperatures based on a diatom record from the north Icelandic shelf, Holocene, 12, 137147, 2002.

Johannessen, T., Jansen, E., Flatøy, A., and Ravelo, A. C.: The relationship between surface water masses, oceanographic fronts and plaeoclimatic proxies in surface sediments of the Greenland, Iceland, Norwegian Seas, NATO, ASI Series, 61-86, 1994.

Johnsen, S., Dahl-Jensen, D., Dansgaard, W., and Gundestrup, N.: Greenland paleotemperatures derived from GRIP bore hole temperature and ice core isotope profiles, Tellus, 5, 624-629, 1995.

Jonkers, L., Brummer, G-J. A., Peeters, F. J. C., van Aken, H. M., and De Jong, M. F.: Seasonal stratification, shell flux, and oxygen isotope dynamics of left-coiling N. pachyderma and T. quin- queloba in the western sub polar North Atlantic, Paleoceanography, 25, PA2204, doi:10.1029/2009PA001849, 2010.

Juggins, S.: C2 1.7.2, available at: http://www.staff.ncl.ac.uk/staff/ stephen.juggins/ (last access: 6 March 2013), 2010.

Kaufman, D., Ager, T. A., Anderson, N. J., Anderson, P. M., Andrews, J. T., Bartlein, P. J., Brubakker, L. B., Coats, L. L., Cwynar, L. C., Duvall, M. L., Dyke, A. S., Edwards, M. E., Eisner, W. R., Gajewski, K., Geirsdottir, A., Hu, F. S., Jennings, A. E., Kaplan, M. R., Kerwin, M. W., Loshkin, A. V., MacDonald, G. M., Miller, G. H., Mock, C. J., Oswald, W. W., Otto-Bliesner, B. L., Porinchu, D. F., Rühland, K., Smol, J. P., Steig, E. J., and Wolfe, B. B.: Holocene thermal maximum in the western Arctic (0-180 N), Quaternary Sci. Rev., 23, 529-560, 2004.

Kinnard, C., Zdanowicz, C. M., Fisher, A. F., Isaksson, E., de Vernal, A., and Thompson, L. G.: Reconstructed changes in Arctic sea ice over the past 1,450 years, Nature, 479, 509-512, doi:10.1038/nature10581, 2011.

Knies, J.: Climate-induced changes in sedimentary regimes for organic matter supply on the continental shelf off northern Norway, Geochim. Cosmochim. Acta, 69, 4631-4647, 2005.

Knudsen, K. L.: Foraminiferer i Kvartær stratigrafi: Laboratorie og fremstillingsteknik samt udvalgte eksempler, Geologisk Tidsskrift, 3, 1-25, 1998.

Koç, N. and Jansen, E.: Response of the high-latitude Northern hemisphere to orbital climate forcing: evidence from the Nordic Seas, Geology, 22, 523-526, 1994.

Koç, N., Jansen, E., and Haflidason, H.: Paleoceanographic reconstructions of surface ocean conditions in the Greenland, Iceland and Norwegian seas through the last $14 \mathrm{ka}$ based on diatoms, Quaternary Sci. Rev., 12, 115-140, 1993.

Kucera, M., Weinelt, M., Kiefer, T., Pflaumann, U., Hayes, A., Weinelt, M., Chen, M. T., Mix, A. C., Barrows, T. T., and Cortijo, E.: Reconstruction of sea-surface temperatures from assemblages of planktonic foraminifera: Multi-technique approach based on geographically constrained calibration data sets and its application to glacial Atlantic and Pacific Oceans, Quaternary Sci. Rev., 24, 951-998, 2005.

Kvingedal, B.: Sea-ice extent and variability in the Nordic Seas, 1967-2002, in: The Nordic seas: An integrated perspective, edited by: Drange, H., Dokken, T., Furevik, T., Gerdes, R., and Berger, W., American Geophysical Union, Geophysical Monograph, 158, 39-49, 2005.

Laskar, J., Robutel, P., Joutel, F., Gastineau, M., Correia, A. C. M., and Levrard, B.: A long-term numerical solution for the insolation quantities of the Earth, Astron. Astrophys., 428, 261-285, 2004.

Le, J. and Shackleton, N. J.: Carbonate dissolution fluctuations in the western equatorial Pacific during the late Quaternary, Paleoceanography, 7, 21-42, 1992.

Le, J. N. and Thunell, R. C.: Modelling planktic foraminiferal assemblage changes and application to sea surface temperature estimation in the western equatorial Pacific Ocean, Mar. Micropaleontol., 28, 211-229, 1996.

Loeng, H.: Features of the physical oceanographic conditions of the Barents Sea, Polar Res., 10, 5-18, 1991.

Lohmann, G. P.: A model for variation in the chemistry of planktonic foraminifera due to secondary calcification and selective dissolution, Paleoceanography, 10, 445-457, 1995. 
Lubinski, D. J., Korsun, S., Polyak, L., Forman, S. L., Lehman, S. J., Herlihy, F. A., and Miller, G. H.: The last deglaciation of the Franz Victoria Trough, northern Barents Sea, Boreas, 25, 89100, 1996.

Mangerud, J. and Gulliksen, S.: Apparent radiocarbon ages of recent marine shells from Norway, Spitsbergen, and Arctic Canada, Quaternary Res., 5, 263-273, 1975.

Mangerud, J., Bondevik, S., Gulliksen, S., Hufthammer, A. K., and Høisæter, T.: Marine 14C reservoir ages for 19th century whales and molluscs from the Nordic Atlantic, Quaternary Sci. Rev., 25, 3228-3245, 2006.

Midttun, L.: Formation of dense bottom water in the Barents Sea, Deep-Sea Res., 32, 1233-1241, 1985.

Moros, M., Emeis, K., Risebrobakken, B., Snowball, I., Kuijpers, A., McManus, J., and Jansen, E.: Sea surface temperatures and ice rafting in the Holocene North Atlantic: Climate influences on northern Europe and Greenland, Quaternary Sci. Rev., 23, 21132126, 2004

Müller, J., Massé, G., Stein, R., and Belt, S. T.: Variability of sea-ice conditions in the Fram Strait over the past 30000 years, Nature Geosci., 2, 772-776, 2009.

Müller, J., Wagner, A., Fahl, K., Stein, R., Prange, M., and Lohman, G.: Towards quantitative sea ice reconstructions in the northern North Atlantic: A combined biomarker and numerical modelling approach, Earth Planet. Sci. Lett., 306, 137-148, 2011.

Müller, J., Werner, K., Stein, R., Fahl, K., Moros, M., and Jansen E.: Holocene cooling culminates in sea ice oscillations in Fram Strait, Quaternary Sci. Rev., 47, 1-14, 2012.

Navarro-Rodriguez, A., Belt, S. T., Knies, J., Brown, T. A.: Mapping recent sea ice conditions in the Barents Sea using the proxy biomarker $\mathrm{IP}_{25}$ : implications for palaeo sea ice reconstructions, Quaternary Sci. Rev., 79, 26-36, 2013.

Orvik, K. A. and Skagseth, Ø.: The impact of the wind stress curl in the North Atlantic on the Atlantic inflow to the Norwegian Sea toward the Arctic, Geophys. Res. Lett., 30, 1884, doi:10.1029/2003GL017932, 2003.

Pflaumann, U., Sarnthein, M., Chapman, M., d'Abreu, L., Funnell, B., Huels, M., Kiefer, T., Maslin, M., Schulz, H., Swallow, J., van Kreveld, S., Vautravers, M., Vogelsang, E., and Weinelt, M.: Glacial North Atlantic sea-surface conditions reconstructed by GLAMAP 2000, Paleoceanography, 18, 1065, doi:10.1029/2002PA000774, 2003.

Polyak, L., Alley, R. B., Andrews, J. T., Brigham-Grette, J., Cronin, T. M., Darby, D. A., Dyke, A. S., Fitzpatrick, J. J., Funder, S., Holland, M., Jennings, A. E., Miller, G. H., O'Regan, M., Savelle, J., Serreze, M., John, K. S., White, J. W. C., and Wolff, E.: History of sea ice in the Arctic, Quaternary Sci. Rev., 29, 1757-1778, 2010.

Pufhl, H. A. and Shackleton, N. J.: Two proximal, high-resolution records of foraminiferal fragmentation and their implications for changes in dissolution, Deep-Sea Res. Pt. I, 51, 809-832, 2004.

Rasmussen, T. L., Thomsen, E., Slubowska, M. A., Jessen, S., Solheim, A., and Koç, N.: Paleoceanographic evolution of the SW Svalbard margin $\left(76{ }^{\circ} \mathrm{N}\right)$ since $20,000{ }^{14} \mathrm{C}$ yr BP, Quaternary Res., 67, 100-114, 2007.

Reimer, P. J., Bard, E., Bayliss, A., Beck, J. W., Blackwell, P. G., Ramsey, C. B., Buck, C. E., Cheng, H., Edwards, R. L., Friedrich, M., Grootes, P. M., Guilderson, T. P., Haflidason, H., Hajdas, I., Hatté, C., Heaton, T. J., Hoffmann, D. L., Hogg, A. G., Hughen,
K. A., Kaiser, K. F., Kromer, B., Manning, S. W., Niu, M., Reimer, R. W., Richards, D. A., Scott, E. M.; Southon, J. R., Staff, R. A., Turney, C. S. M., and Van Der Plicht, J.: IntCal13 and Marine13 radiocarbon age calibration curves, 0-50 000 years cal BP, Radiocarbon, 55, 1869-1887, 2013.

Reynolds, L. and Thunnel, R. C.: Seasonal succession of planktonic foraminifera in the subpolar North Pacific, J. Foramin. Res., 15, 282-301, 1985.

Risebrobakken, B., Jansen, E., Andersson, C., Mjelde, E., and Hevrøy, K.: A high-resolution study of Holocene paleoclimatic and paleoceanographic changes in the Nordic Seas, Paleoceanography, 18, 1017, doi:10.1029/2002PA000764, 2003.

Risebrobakken, B., Morros, M., Ivanova, E. V., Chistyakova, N., and Rosenberg, R.: Climate and oceanographic variability in the SW Barents Sea during the Holocene, Holocene, 20, 609-621, 2010.

Risebrobakken, B., Dokken, T., Smedsrud, L. H., Andersson, C., Jansen, E., Moros, M., and Ivanova, E. V.: Early Holocene temperature variability in the Nordic Seas: The role of oceanic heat advection versus changes in orbital forcing, Paleoceanography, 26, PA4206, doi:10.1029/2011PA002117, 2011.

Rousse, S., Kissel, C., Laj, C., Eiriksson, J., and Knudsen, K. L.: Holocene centennial to millenial-scale climatic variability: Evidence from high resolution magnetic analyses of the last $10 \mathrm{cal}$. kyr of North Iceland (core MD99-2275), Earth Planet. Sci. Lett., 242, 390-405, 2006.

Rudels, B., Anderson, L. G., and Jones, E. P.: Formation and evolution of the surface mixed layer and the halocline of the Arctic Ocean, J. Geophys. Res., 101, 8807-8821, 1996.

Rudels, B., Björk, G., Nilsson, J., Winsor, P., Lake, I., and Nohr, C.: The interaction between waters from the Arctic Ocean and the Nordic Seas north of Fram Strait and along the East Greenland Current: Results from the Arctic Ocean-O2 Oden expedition, J. Marine Syst., 55, 1-30, 2005.

Rüther, D. C., Bjarnadóttir, L. J., Junttila, J., Husum, K., Rasmussen, T. L., Lucchi, R. G., and Andreassen, K.: Pattern and timing of the northwestern Barents Sea Ice Sheet deglaciation and indications of episodic Holocene deposition, Boreas, doi:10.1111/j.1502-3885.2011.00244.x, ISSN 0300-9483, 2012.

Sætre, R.: Short term variability and small-scale features, in: The Norwegian coastal current, edited by: Sætre, R, Tapir academic press, Trondheim, 89-99, 2007.

Saito, T., Thompson, P. R., and Breger, D.: Systematic index of recent and pleistocene planktonic foraminifera, University of Tokyo press, Tokyo, 1981.

Sakshaug, E.: Biomass and productivity distributions and their variability in the Barents Sea, ICES J. Marine Sci., 54, 341-350, 1997.

Sakshaug, E., Bjørge, A., Gulliksen, B., Loeng, H., and Mehlum, F.: Økosystem Barentshavet, Norges Allmenvitenskapelige Forskningsråd, Norges Fiskeriforskningsråd, Miljøverndepartementet, 304, 1992.

Sarnthein, M., Jansen, E., Weinelt, M., Arnold, M., Duplessy, J., Erlenkeuser, H., Flatøy, A., Johannessen, G., Johannessen, T., Jung, S., Koç, N., Labeyrie, L., Maslin, M., Pflaumann, U., and Schulz, H.: Variations in Atlantic surface ocean paleoceanography, 50 $80^{\circ} \mathrm{N}$ : A time-slice record of the last 30,000 years, Paleoceanography, 10, 1063-1094, doi:10.1029/95PA01453, 1995. 
Sarnthein, M., Van Kreveld, S., Erlenkeuser, H., Grootes, P. M., Kucera, M., Pflaumann, U., and Schulz, M.: Centennial-tomillennial-scale periodicities of Holocene climate and sediment injections off the western Barents shelf, $75^{\circ} \mathrm{N}$, Boreas, 32, 447461, 2003.

Schiermeier, Q.: Record shrinkage confounds models and portends atmospheric and ecological change, Nature, 489, 185-186, 2012.

Scott, D. B., Schell, T., Rochon, A., and Blasco, S.: Modern benthic foraminifera in the surface sediments of the Beaufort shelf, slope and Mackenzie Trough, Beaufort Sea, Canada: Taxonomy and summary of surficial distributions, J. Foramin. Res., 38, 228 250,2008

Semenov, V. A., Park, W., and Latif, M.: Barents Sea inflow shutdown: A new mechanism for rapid climate changes, Geophys. Res. Lett., 36, L14709, doi:10.1029/2009GL038911, 2009.

Slubowska, M. A., Koç, N., Rasmussen, T. L., and KlitgaardKristensen, D.: Changes in the flow of Atlantic water into the Arctic Ocean since the last deglaciation: Evidence from the northern Svalbard continental margin, 80N, Paleoceonography, 20, PA4014, doi:10.1029/2005PA001141, 2005.

Slubowska-Woldengen, M., Rasmussen, T. L., Koç, N., KlitgaardKristensen, D., Nilsen, F., and Solheim, A.: Advection of Atlantic Water to the western and northern Svalbard shelf since 17500 cal yr BP, Quaternary Sci. Rev., 26, 463-478, 2007.

Smith, S. L., Smith, W. O., Codispoti, L. A., and Wilson, D. L.: Biological observations in the marginal ice zone of the East Greenland Sea, J. Marine Res., 43, 693-717, 1985.

Smith, W. O. and Sakshaug, E.: Polar phytoplankton, in: Polar oceanography, edited by: Smith, W. O., Part B: Chemistry, Biology and Geology, Academic Press, New York, 447-525, 1990.

Solignac, S., Giraudeau, J., and De Vernal, A.: Holocene sea surface conditions in the western North Atlantic: Spatial and temporal heterogeneities, Paleoceanography, 21, PA2004, doi:10.1029/2005PA001175, 2006.

Spielhagen, R. F., Werner, K., Aagaard Sørensen, S., Zamelczyk, K., Kandiano, E., Budeus, G., Husum, K., Marchitto, T. M., and Hald, M.: Enhanced modern heat transfer to the Arctic by warm Atlantic water, Science, 331, 450, doi:10.1126/science.1197397, 2011.

Stein, R. and Fahl, K.: Biomarker proxy shows potential for studying the entire Quaternary Arctic sea ice history, Org. Geochem., 55, 98-102, 2013.

Steinsund, P. I. and Hald, M.: Recent carbonate dissolution in the Barents Sea: Paleoceanographic applications, Mar. Geol., 117, 303-316, 1994.
Stroeve, J. C., Kattsov, V., Barrett, A., Serreze, M., Pavlova, T., Holland, M., and Meier, W. N.: Trends in Arctic sea ice extent from CMIP5, CMIP3 and observations, Geophys. Res. Lett., 39, L16502, doi:10.1029/2012GL052676, 2012.

Stuiver, M. and Reimer, P. J.: Extended 14C data base and revised CALIB 3.0 14C age calibration program, Radiocarbon, 35, 215230, 1993

Swift, J. H.: The Arctic waters, in: The Nordic Seas, edited by: Hurdle, B. G., Springer New York, 129-153, 1986.

Telford, R. J. and Birks, H. J. B.: The secret assumption of transfer functions: Problems with spatial autocorrelation in evaluating model performance, Quaternary Sci. Rev., 24, 2173-2179, 2005.

Ter Braak, C. J. F. and Juggins, S.: Weighted averaging partial least squares regression (WA-PLS): An improved method for reconstructing environmental variables from species assemblages, Hydrobiologia, 269/270, 485-502, 1993.

Thunell, R. C. and Honjo, S.: Calcite dissolution and the modification of planktonic foraminiferal assemblages, Mar. Micropaleontol., 6, 169-182, 1981.

Vare, L. L., Massé, G., and Belt, S.: A biomarker-based reconstruction of sea ice conditions for the Barents Sea in recent centuries, Holocene, 20, 637-643, 2010.

Vinje, T. E.: Sea ice conditions in the European sector of the marginal seas of the Arctic, 1966-75, Aarb. Nor. Polarinst., 1975, 163-174, 1977.

Volkmann, R.: Planktic foraminifers in the outer Laptev Sea and the Fram Strait: Modern distribution and ecology, J. Foramin. Res., 30, 157-176, 2000.

Voronina, E., Polyak, L., de Vernal, A., and Peyron, O.: Holocene variations of sea-surface conditions in the southeastern Barents Sea, reconstructed from dinoflagellate cyst assemblages, J. Quaternary Sci., 16, 717-726, 2001.

Werner, K., Spielhagen, R. F., Bauch, D., Hass, H. C., and Kandiano, E.: Atlantic Water advection versus sea-ice advances in the eastern Fram Strait during the last 9 ka: Multiproxy evidence for a two-phase Holocene, Paleoceanography, 28, 283295, doi:10.1002/palo.20028, 2013.

Zamelczyk, K., Rasmussen, T. L., Husum, K., Haflidason, H., de Vernal, A., Krogh Ravna, E., Hald, M., and Hillaire-Marcel, C.: Paleoceanographic changes and calcium carbonate dissolution in the central Fram Strait during the last $20 \mathrm{ka}$ yr, Quaternary Res. 78, 405-416, 2012. 